\title{
1 Brasilia, Polisemia de um ícono Del Patrimonio Modernista
}

Edson Farias ${ }^{*}$

Bueno, me gustaría exteriorizar el placer de estar aquí en esta universidad. Todos los que hacemos trabajo intelectual conocemos la importancia de los diálogos. Por eso mismo, estoy muy agradecido del Departamento de Antropología y de toda la comunidad de la Facultad de Ciencias Sociales. Sobre todo, le doy a las gracias a la profesora María Francisca Márquez por la invitación de, a quien conocí en Brasil en el 2012. En aquél entonces, después de observar las afinidades de intereses de investigación en relación a las cuestiones urbanas, se inició un intercambio de ideas que ahora culmina en esta oportunidad: presentarles algunas de las conclusiones extraídas sobre Brasilia, la ciudad de la que provengo. Y así escuchar sus impresiones.

Con el fin de situar a Brasilia en el contexto brasileño, debemos recordar que se encuentra en la gran región Centro(Medio)-Oeste, que sólo a partir de la década de 1960 ha Dossiê Expressões Artísticas e Mulheres Arquivos do CMD, Volume 2, N. 2. Jul/Dez 2014 visto un asentamiento más intenso y una mayor integración con el resto del país. Uno de los factores que explican este incremento en la ocupación de la región es el traslado de la capital federal de la costa para el interior. Otro factor más reciente, de mediados de la década de 1970, es la expansión de la frontera agrícola orientada especialmente para el cultivo de cereales.

Imagen: Las regiones de Brasil 


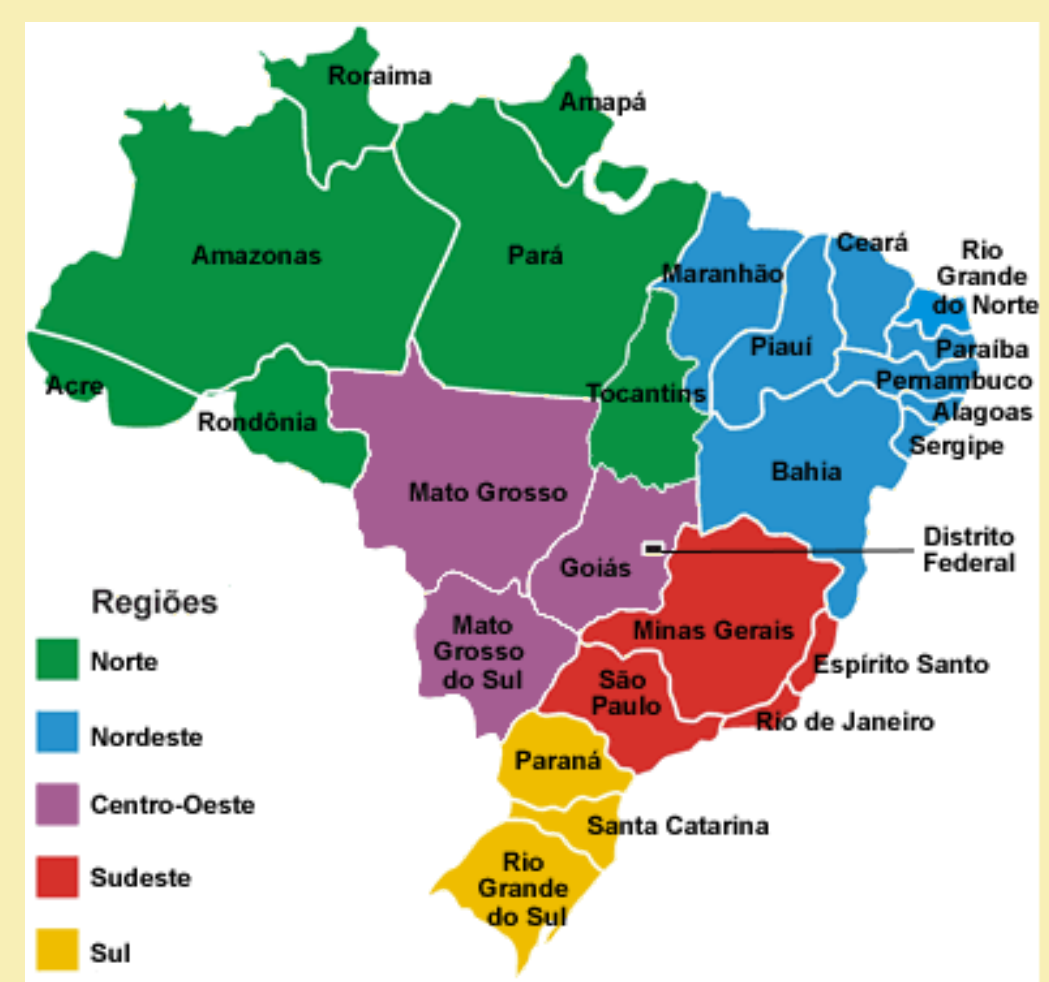



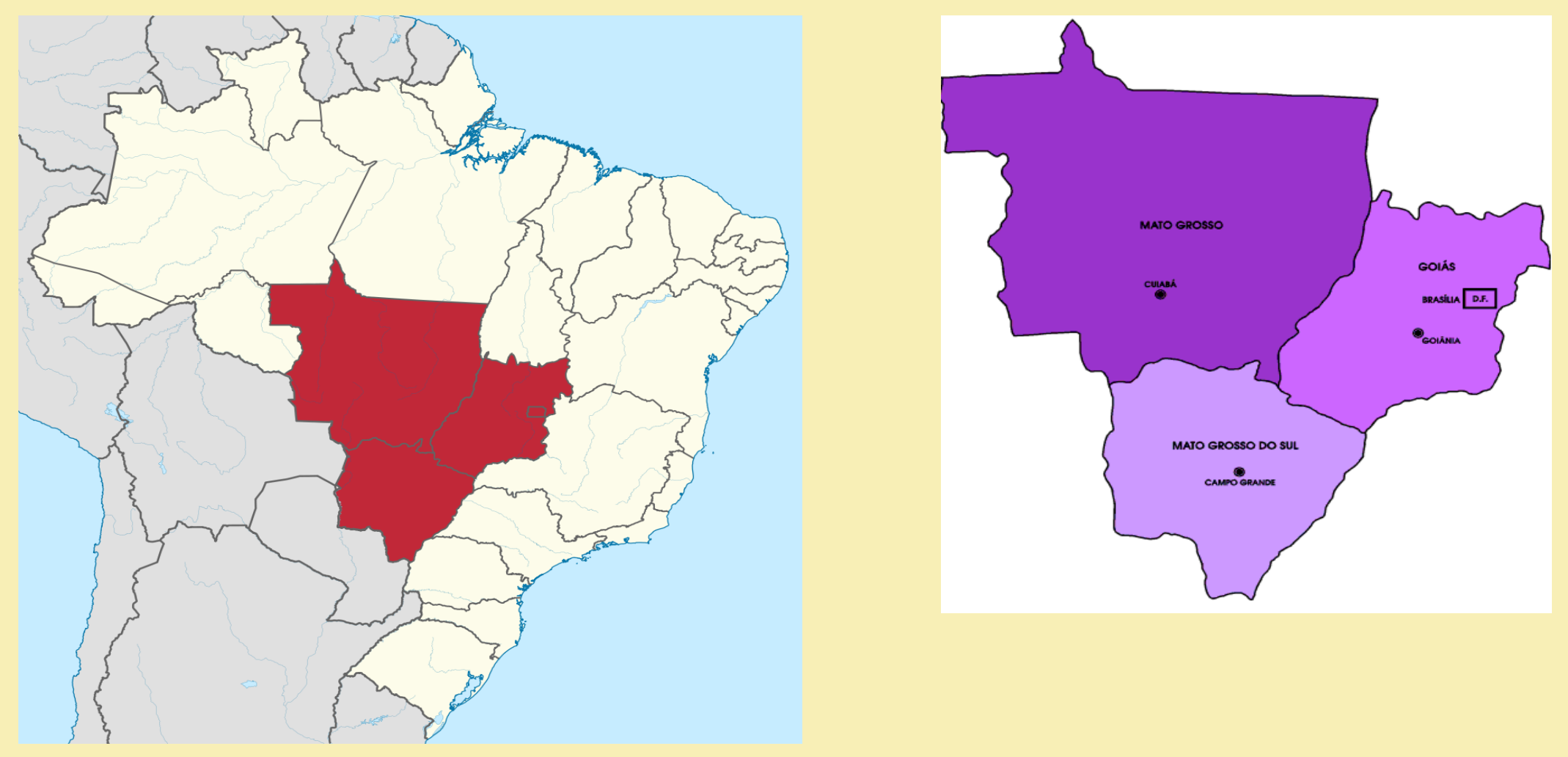

Imagen: Mapa del Distrito Federal 


\section{Edson Farias}

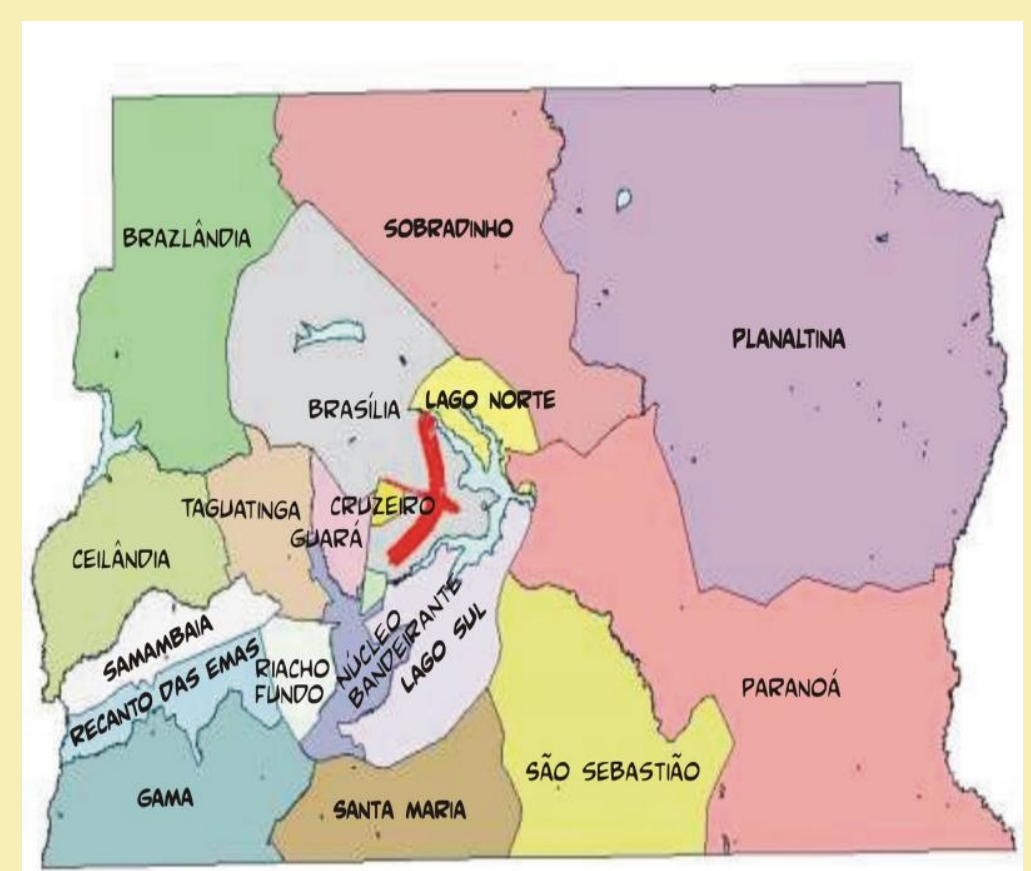

De acuerdo con el censo realizado por el Instituto Brasileño de Geografía y Estadística (IBGE), en 2010, la población del Distrito Federal es de aproximadamente 2 millones y 500 mil personas. La población se distribuye en 31 regiones administrativas, con una superficie total de $5.779 .999 \mathrm{~km}^{2}$.

Aunque no demuestra el mayor producto interno bruto de la federación brasileña, el Distrito Federal, donde se ubica la ciudadDossiê Expressões Artísticas e Mulheres

Arquivos do CMD, Volume 2, N. 2. Jul/Dez 2014

\section{Imagen: La RIDE}

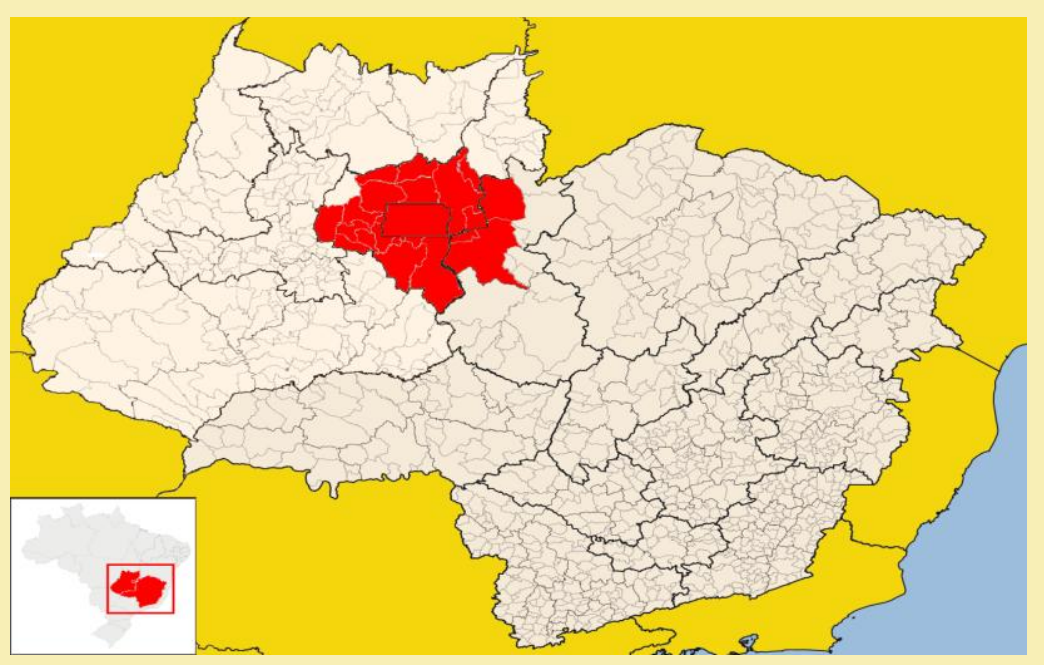

estado de Brasilia, cuenta con el mayor ingreso per cápita. Y posee la tasa de escolaridad per cápita más alta.

Sin embargo, este perfil no es suficiente para presentar una silueta más coherente de los aspectos que definen a Brasilia en la actualidad. Esto se debe a que las 18 ciudades ubicadas en los estados de Goiás y Minas Gerais, pero que se encuentran en los bordes del Distrito Federal, comprenden la Red del desarrollo del DF y Alrededores - RIDE. Considerándola, esta cantidad territorial 
representa un área metropolitana poblada por cerca de 3.506.967 habitantes. Colocándose así en el tercer lugar entre las principales zonas metropolitanas del país.

No obstante, los planificadores y los geógrafos no han llegado a un consenso si Brasilia y la RIDE constituyen o no un área metropolitana. La falta de coincidencia entre las opiniones de los planificadores y los geógrafos se refiere a diversos aspectos. Sin embargo, coinciden en señalar: no estaríamos ante una metrópoli debido al hecho de que carece de una conurbación eficaz en la territorialidad del Distrito Federal y las ciudades de RIDE.

Sabemos que desde el aporte original de Simmel y de la Escuela de Chicago, la metrópoli moderna ha sido diseñada de acuerdo con el criterio de la densidad urbana. Estas concepciones encuentran pruebas empíricas en las ciudades gemelas de los Estados Unidos. Estas ciudades se han vuelto referencias del concepto de metrópoli. Al mismo tiempo, habitan un imaginario propio sobre los escenarios y estilos de vida urbanos, en la cultura histórica de la modernidad.

Pero si creemos que esta misma cultura histórica es multifacética, nos vemos motivados a creer que Brasilia y otras experiencias en todo el mundo dejan abierta las posibilidades de plantear cuestiones fundamentales al marco teórico que prevalece Dossiê Expressões Artísticas e Mulheres Arquivos do CMD, Volume 2, N. 2. Jul/Dez 2014 en los estudios, investigaciones y reflexiones sobre las metrópolis.

Para nuestros intereses de investigación, lo que realmente importa es cómo un sentido de unidad urbana es compartido por diferentes grupos humanos en el contexto fuertemente marcado por la pulverización. Esta seria desde nuestra perspectiva la particularidad Brasiliense con respecto a la diversidad empírica entre las metrópolis y esto juega, por lo tanto, un papel estratégico en la forma misma de pensar contextos metropolitanos.

En 2010, cuando la capital de Brasil celebró su quincuagésimo aniversario, decidimos afrontar este contexto metropolitano. Queríamos conocerlo mejor, pero teniendo en cuenta la singularidad por la que se ha decretado en su centro como un patrimonio de la humanidad, es decir, el complejo modernista arquitectónico y urbanista, firmado por Lúcio Costa y Oscar Niemeyer.

Así, se propuso el proyecto de investigación $O$ Ícone e a Metrópole: o patrimônio arquitetônico modernista nas trajetórias dos usos do espaço urbano na trama metropolitana de Brasília. Realizada por un grupo de nueve estudiantes de pregrado y posgrado en Ciencias Sociales de la Universidad de Brasilia, bajo mi coordinación, la investigación apunta a observar en qué medida el patrimonio urbanista y arquitectónico modernista llamado "Plano 
Piloto" desempeña un papel estratégico en la orientación cognitiva y normativa de los usos socio-espaciales que se hacen del contexto metropolitano brasiliense. El proyecto se completó en 2013. Los resultados fueron compilados en el libro Retas que se Prolongam em Curvas: tensões nos usos do contexto metropolitano brasiliense, que está en la fase de edición.

En forma de alas (norte y sur), que cuenta en su centro El Eixo (eje) Monumental con la Esplanada de los Ministerios y los palacios donde se encuentram los tres poderes de la república, además de la catedral católica, El Plano Piloto concentra las funciones políticas y administrativas de la capital y también sus principales servicios. Viven allí algunos de los sectores más pudientes de la burocracia estatal brasileña: en las super cuadras de las alas norte y sur, divididas por el Eixo (eje) Rodoviário. Cada una de las 17 super cuadras se compone de 17 bloques de viviendas. Estos edificios deben ser, en principio, de cuatro plantas. También tienen plazas y el paisaje incluye muchos árboles. En las zonas intermedias entre las super cuadras se encuentran zonas de comercio y servicios. Estos se llaman entrequadras o "comerciales".

También en el Plano Piloto está la terminal de autobuses, donde los micros parten hacia otras regiones administrativas del Distrito Federal y las ciudades que están su alrededor.

Dossiê Expressões Artísticas e Mulheres

Arquivos do CMD, Volume 2, N. 2. Jul/Dez 2014

\section{Imágenes: Plano Piloto}

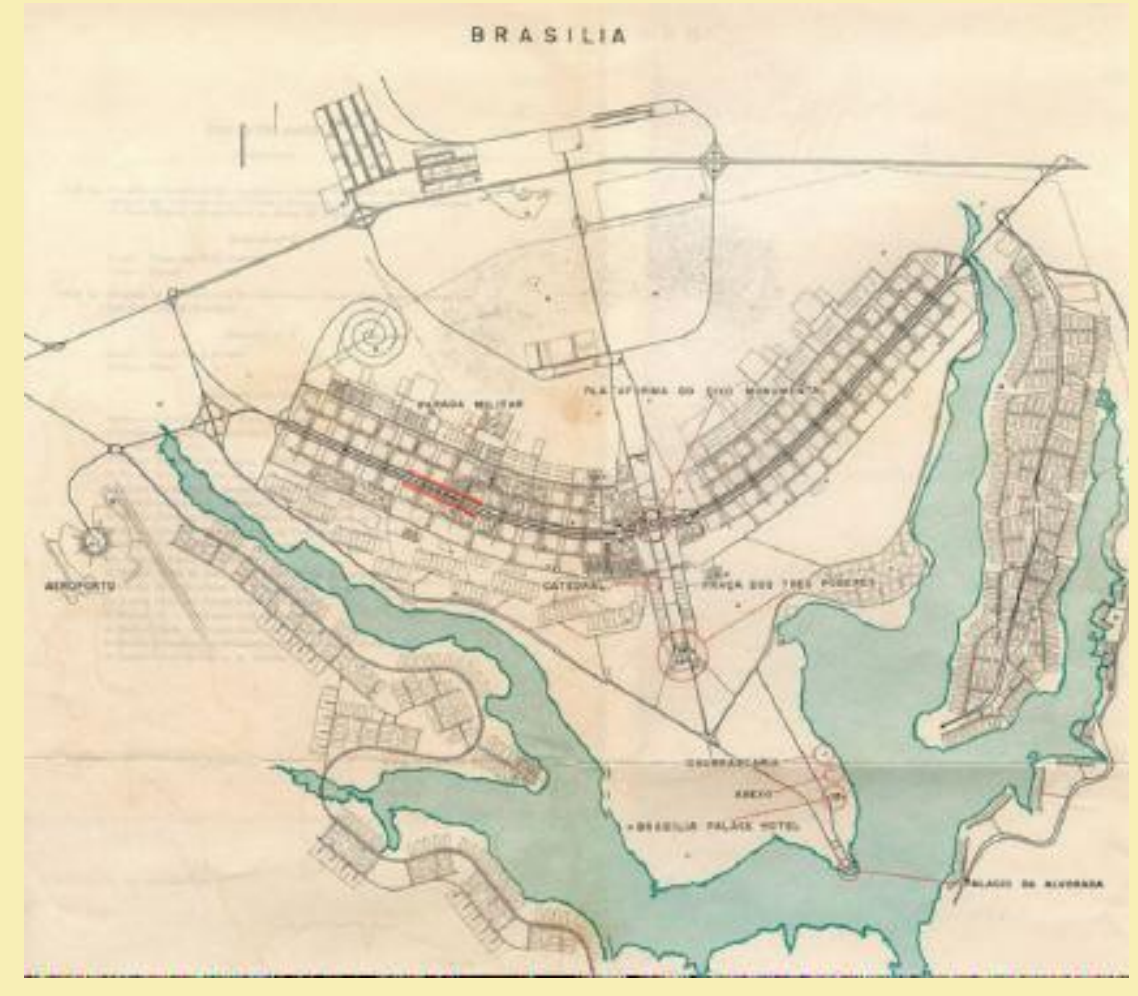



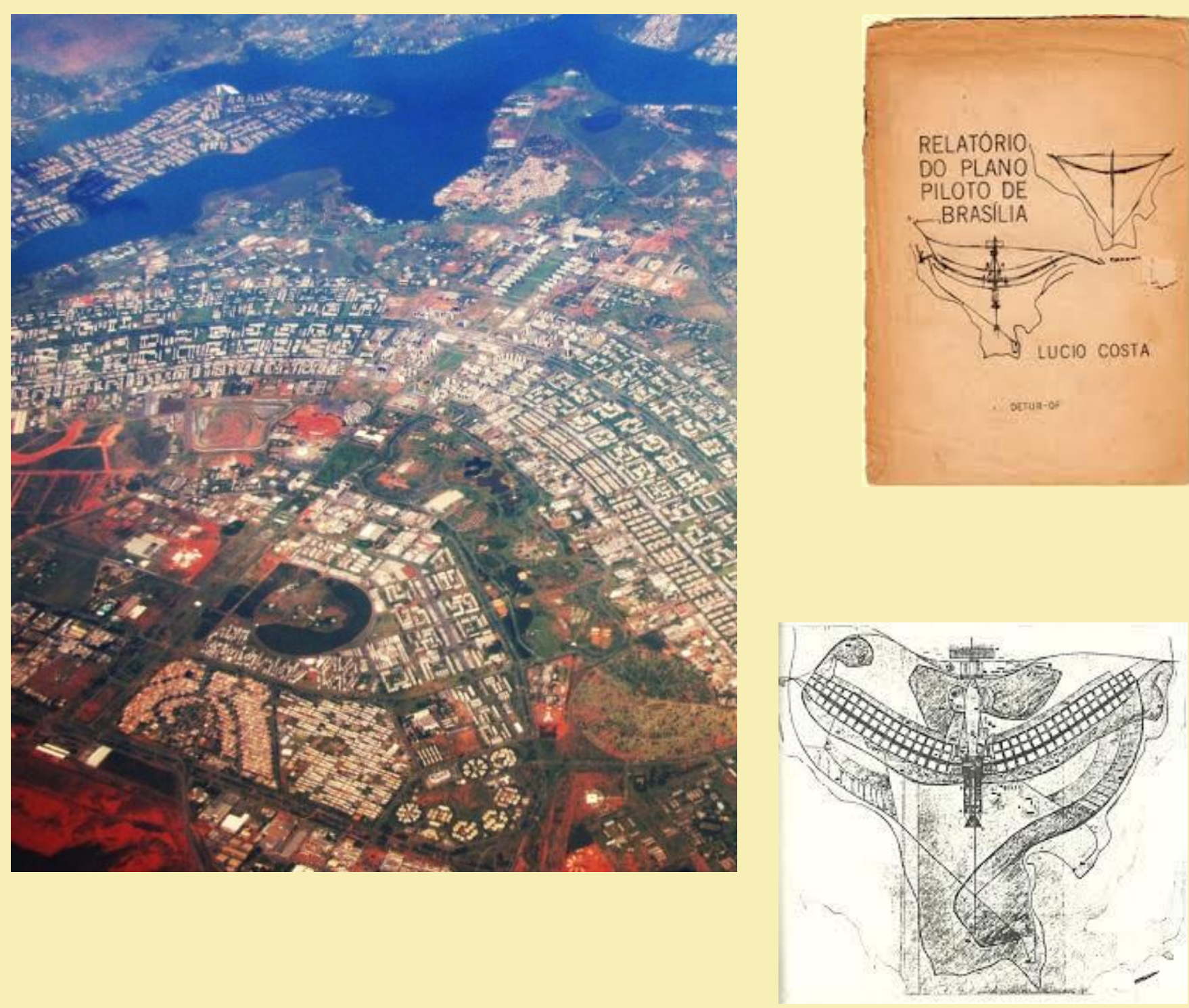

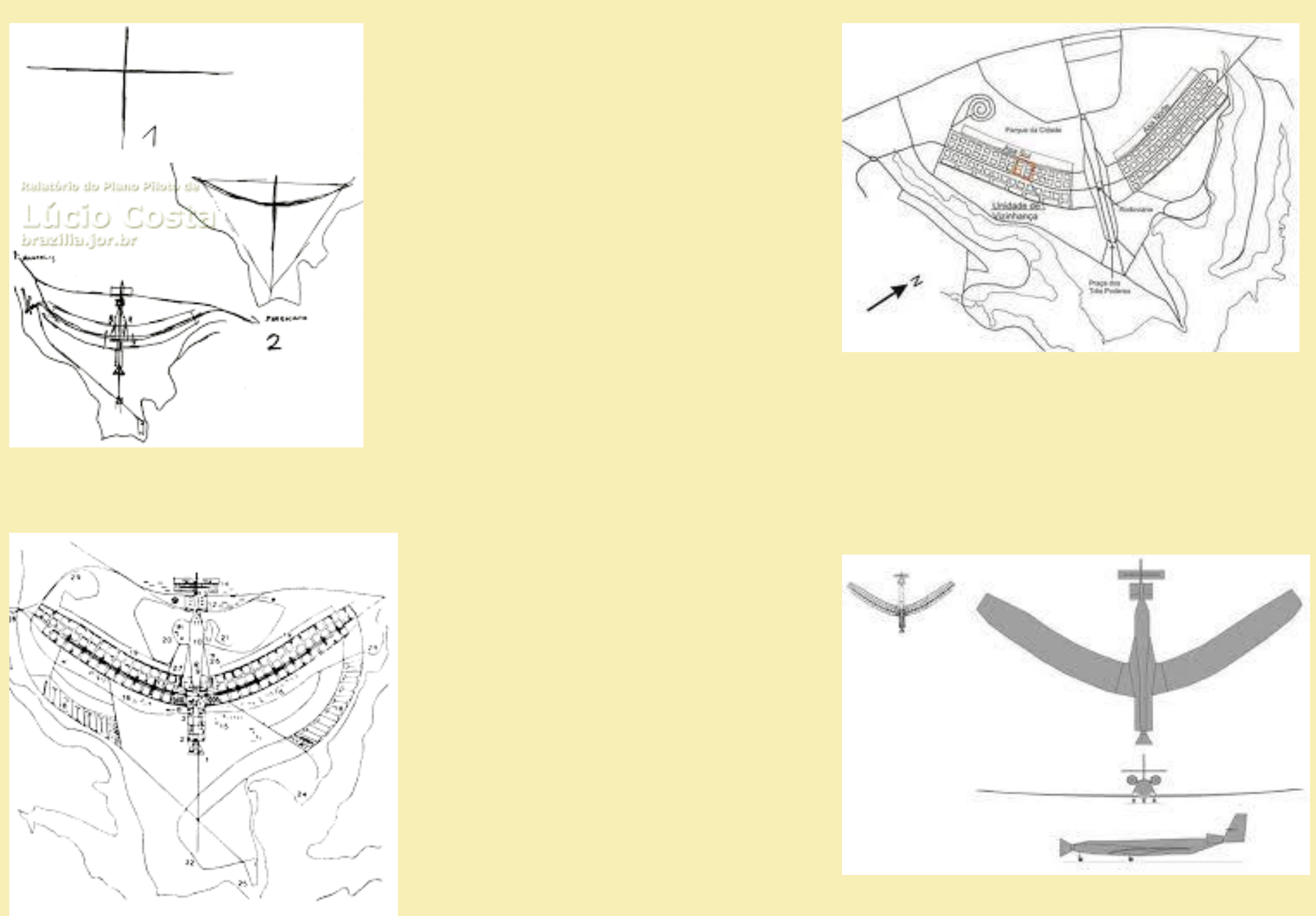


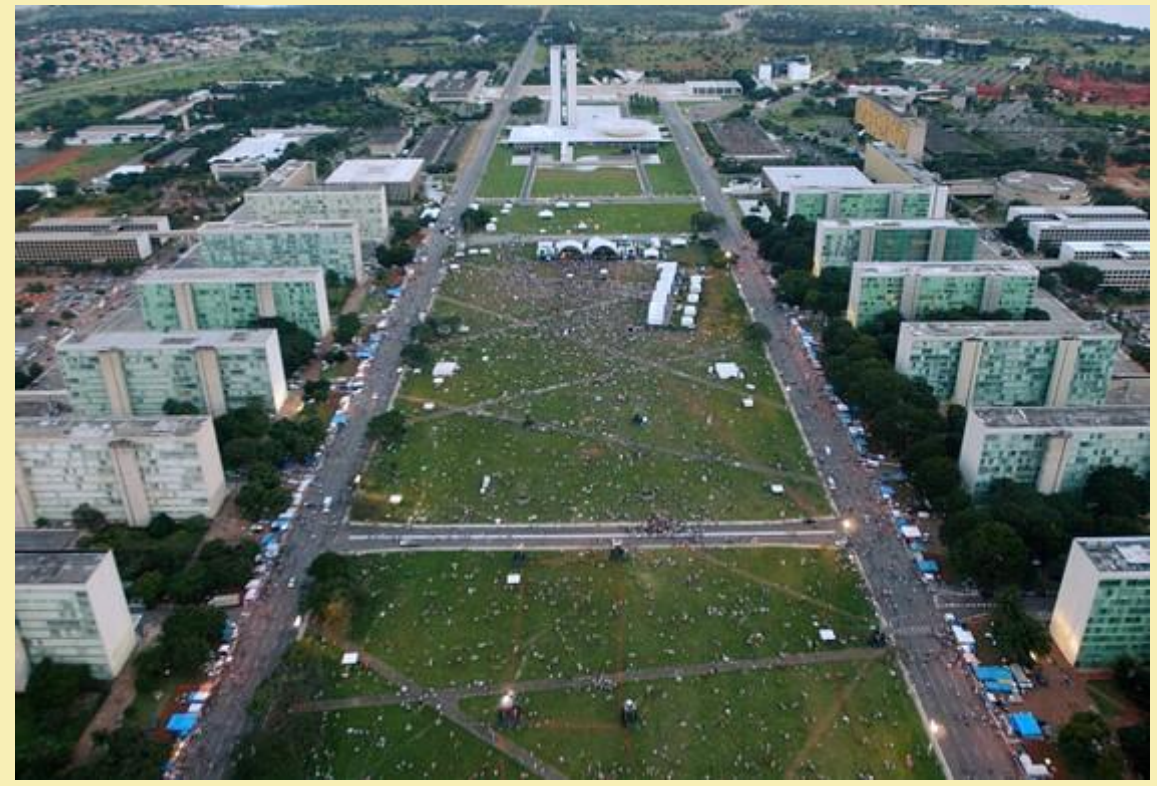




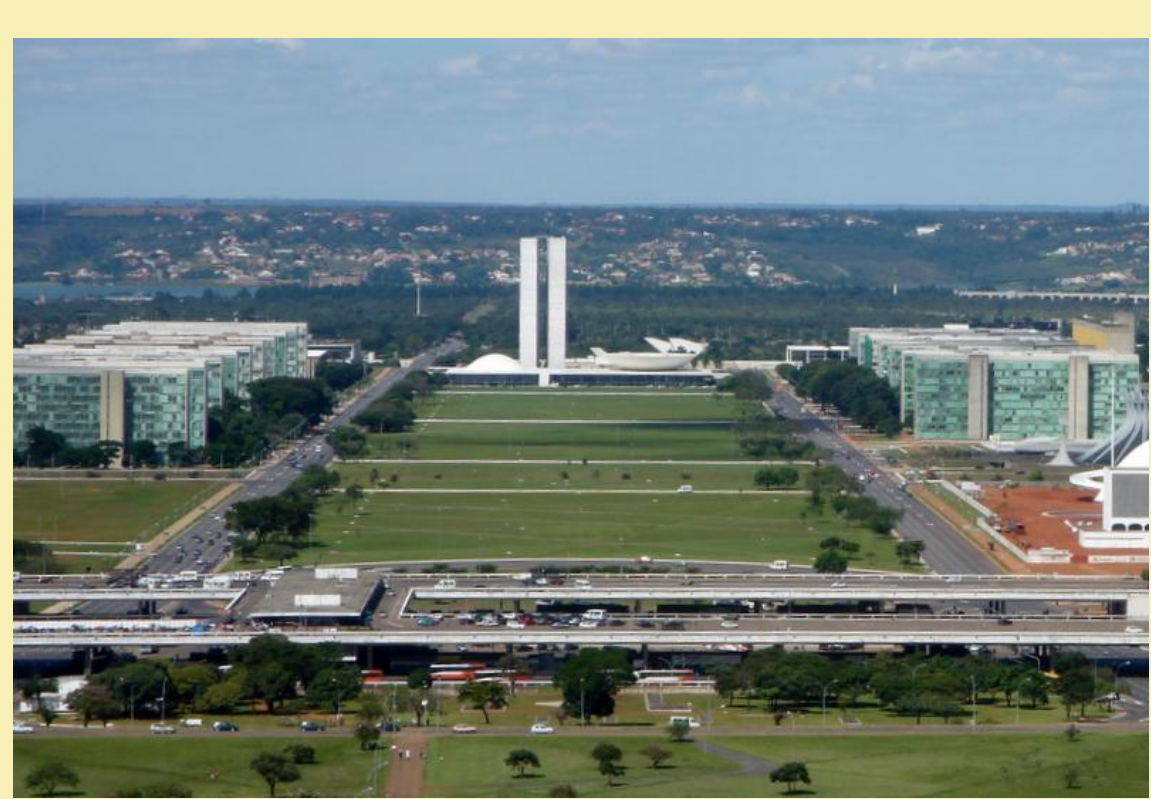

Imágenes: El Eixo Rodiviário, Super cuadras norte y sul y terminal de Plano Piloto

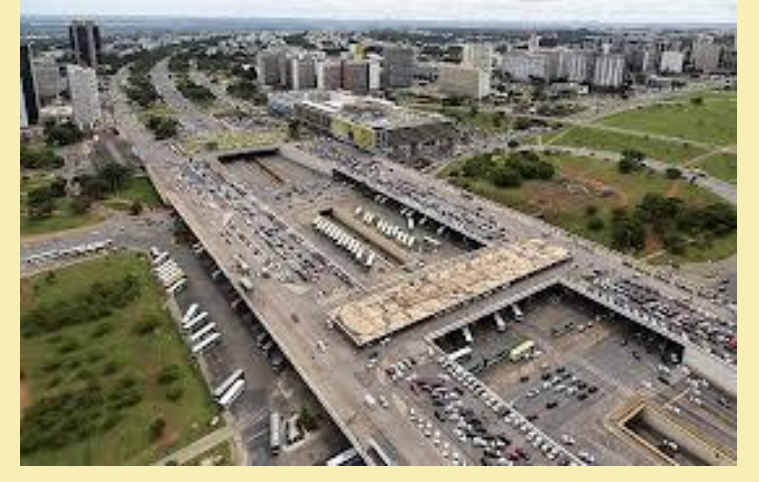



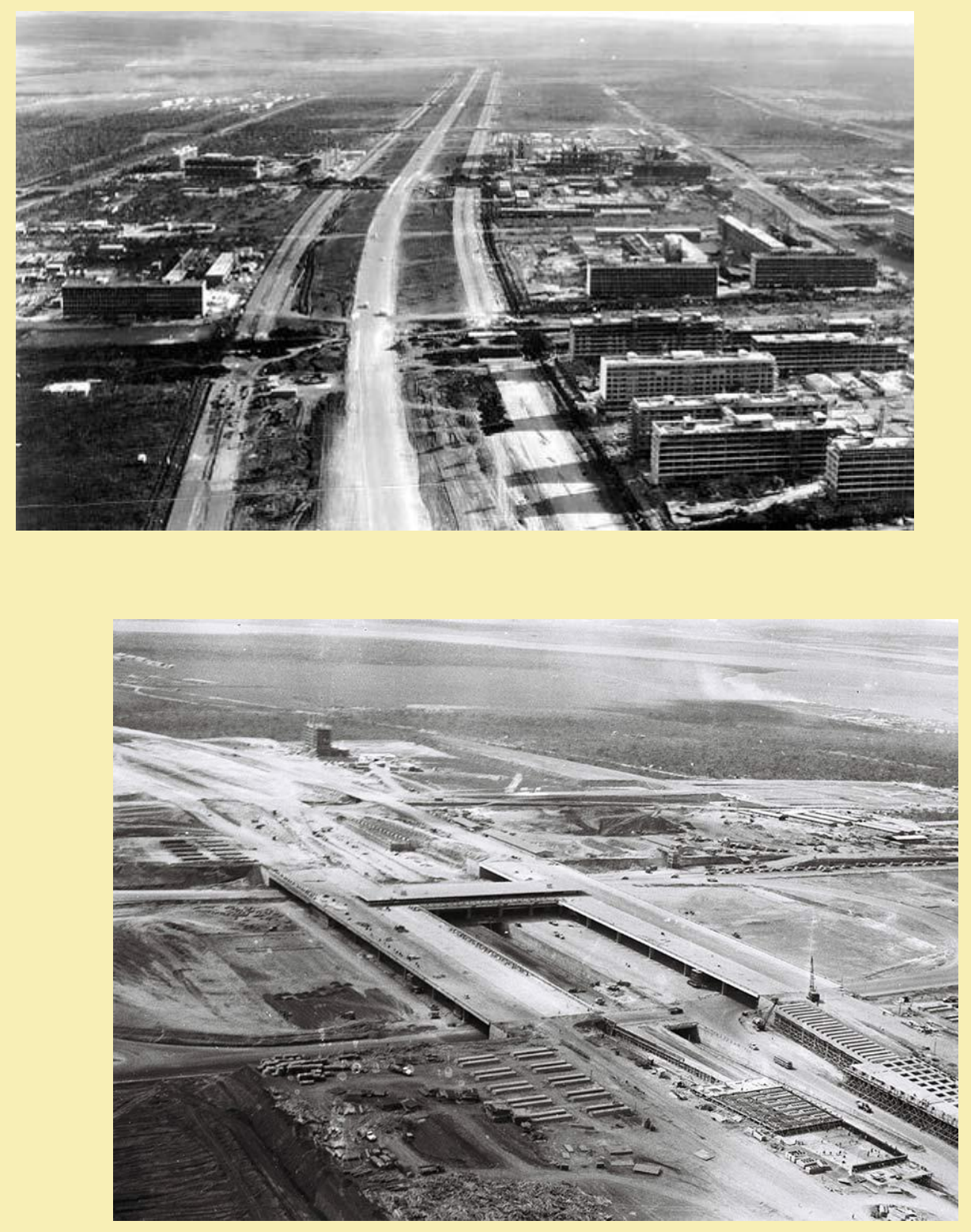


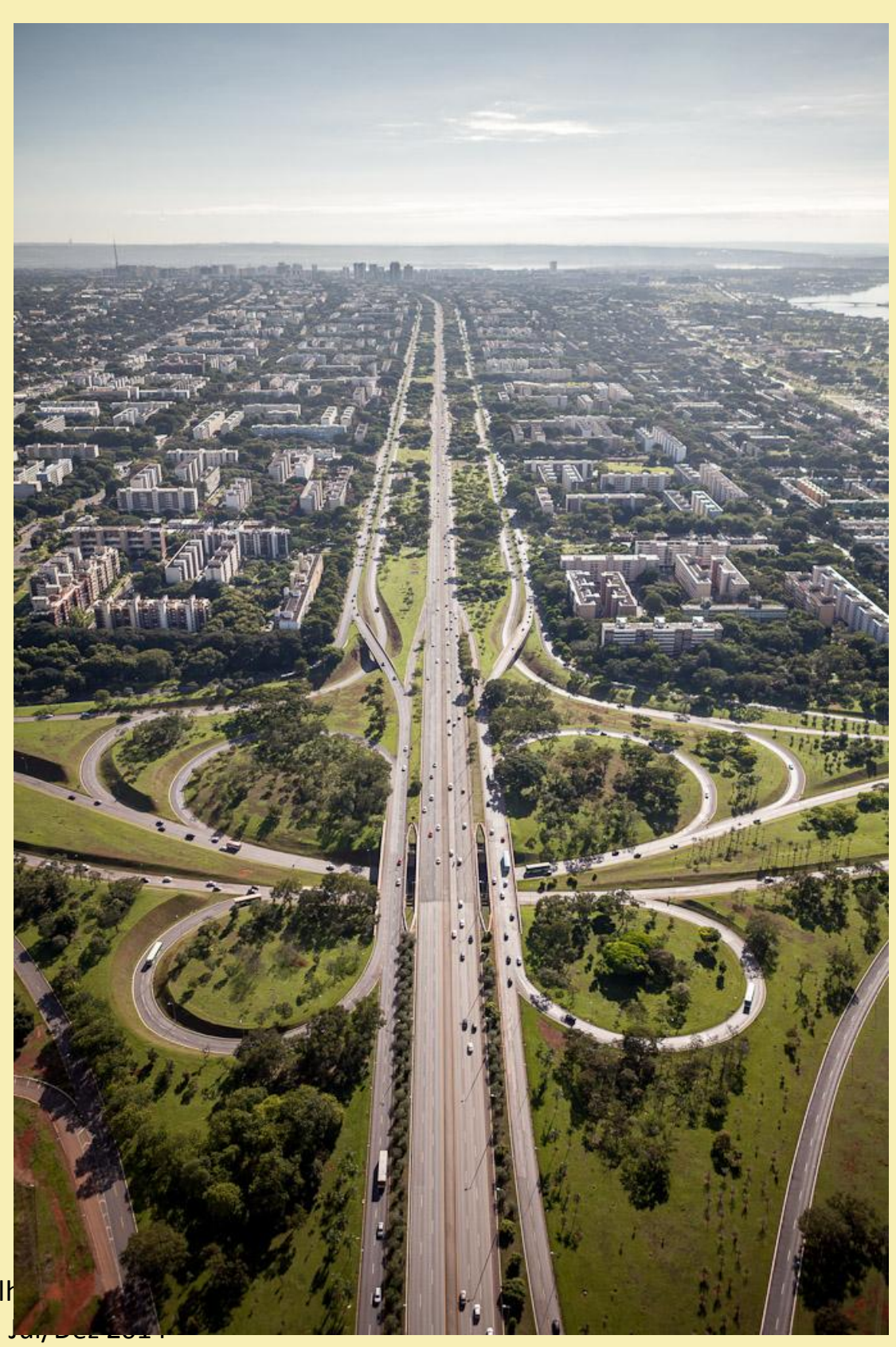




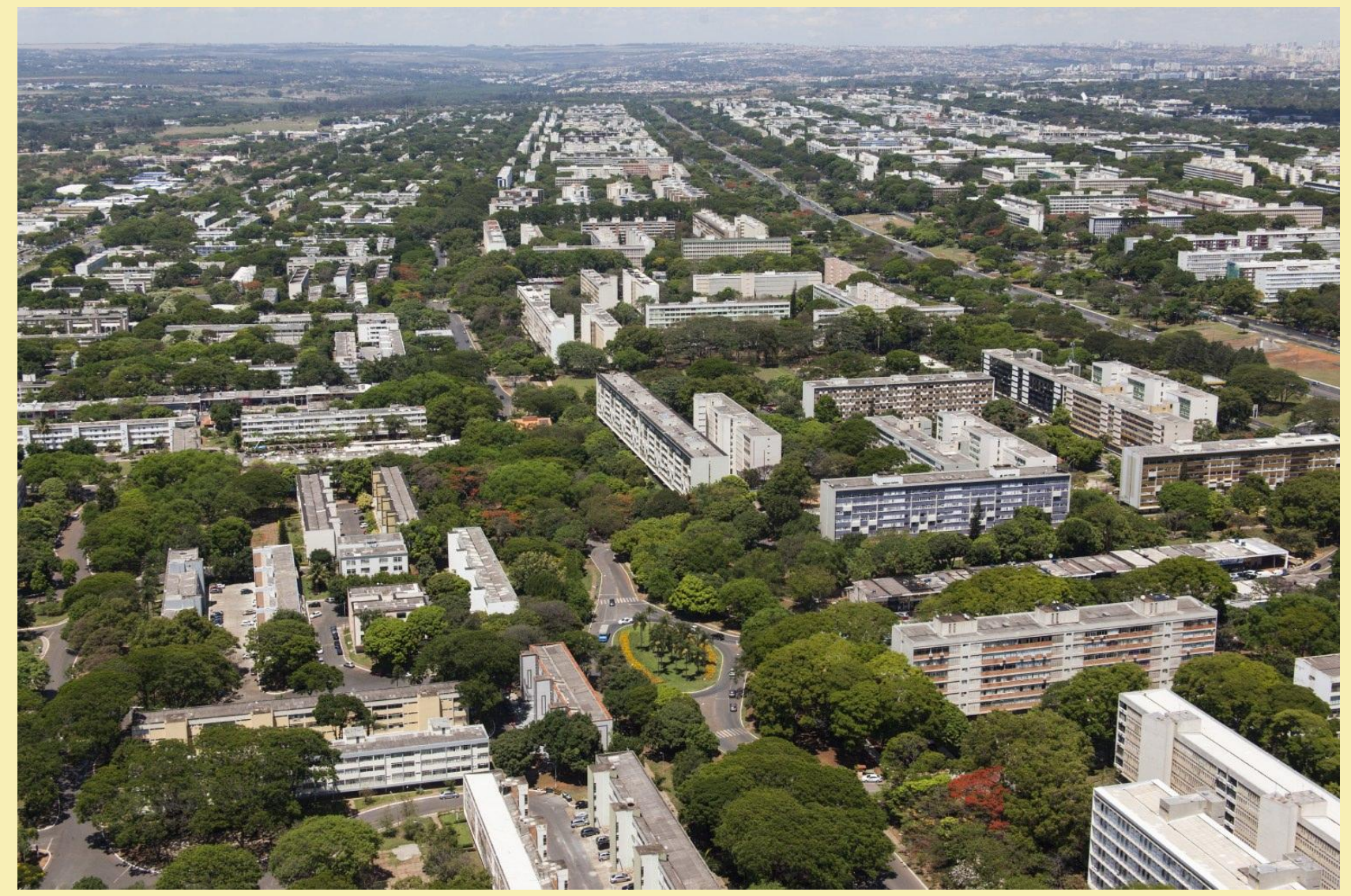




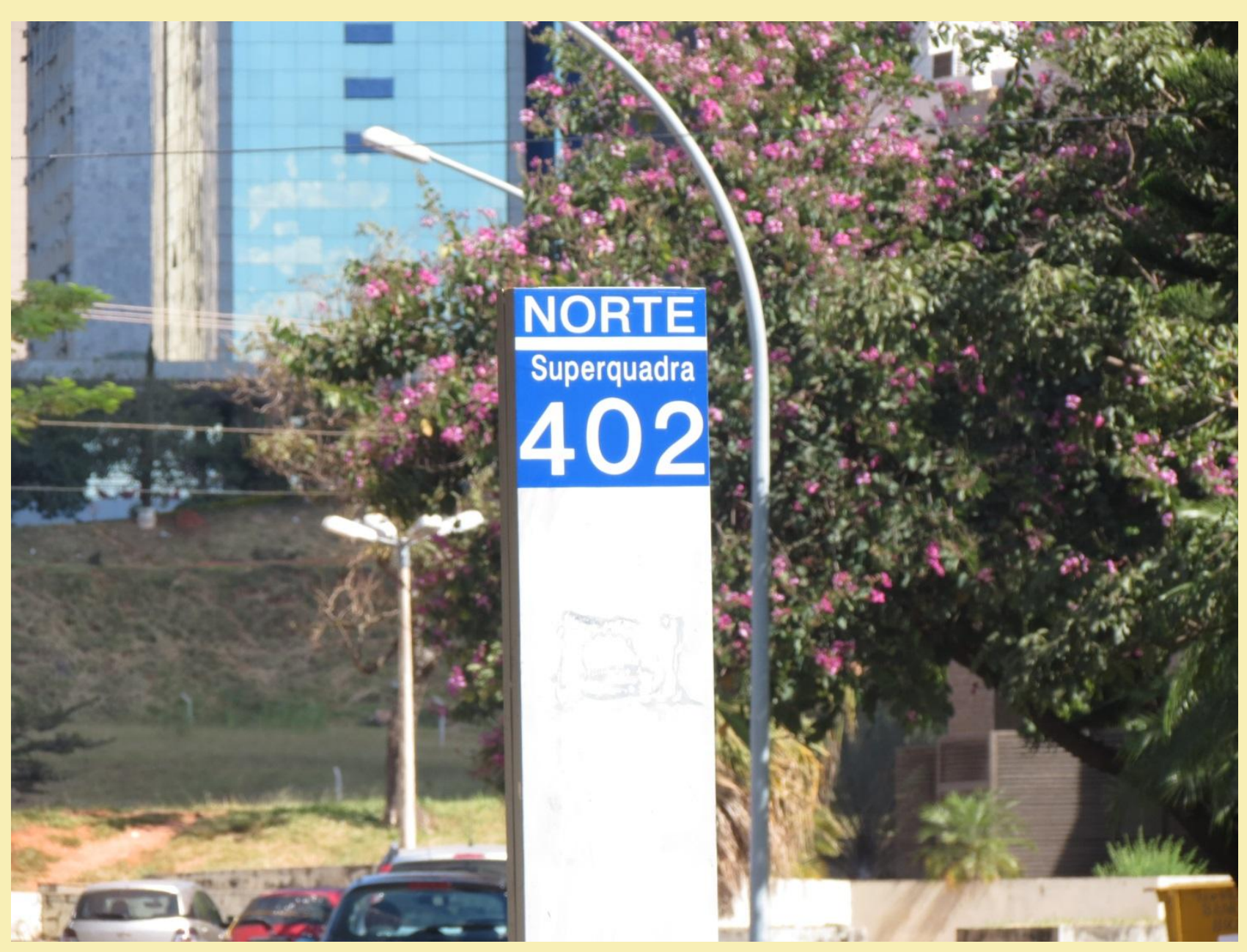




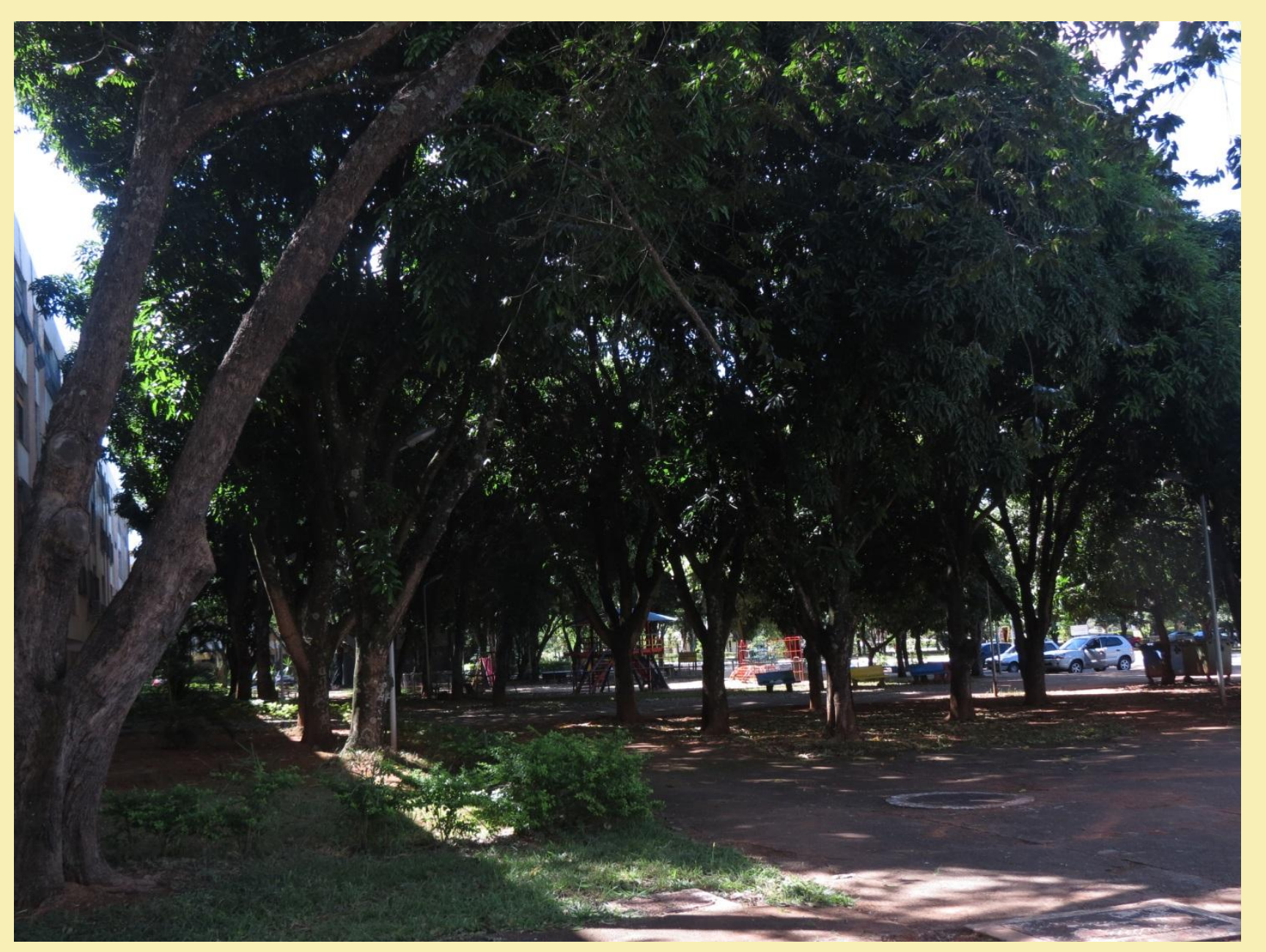




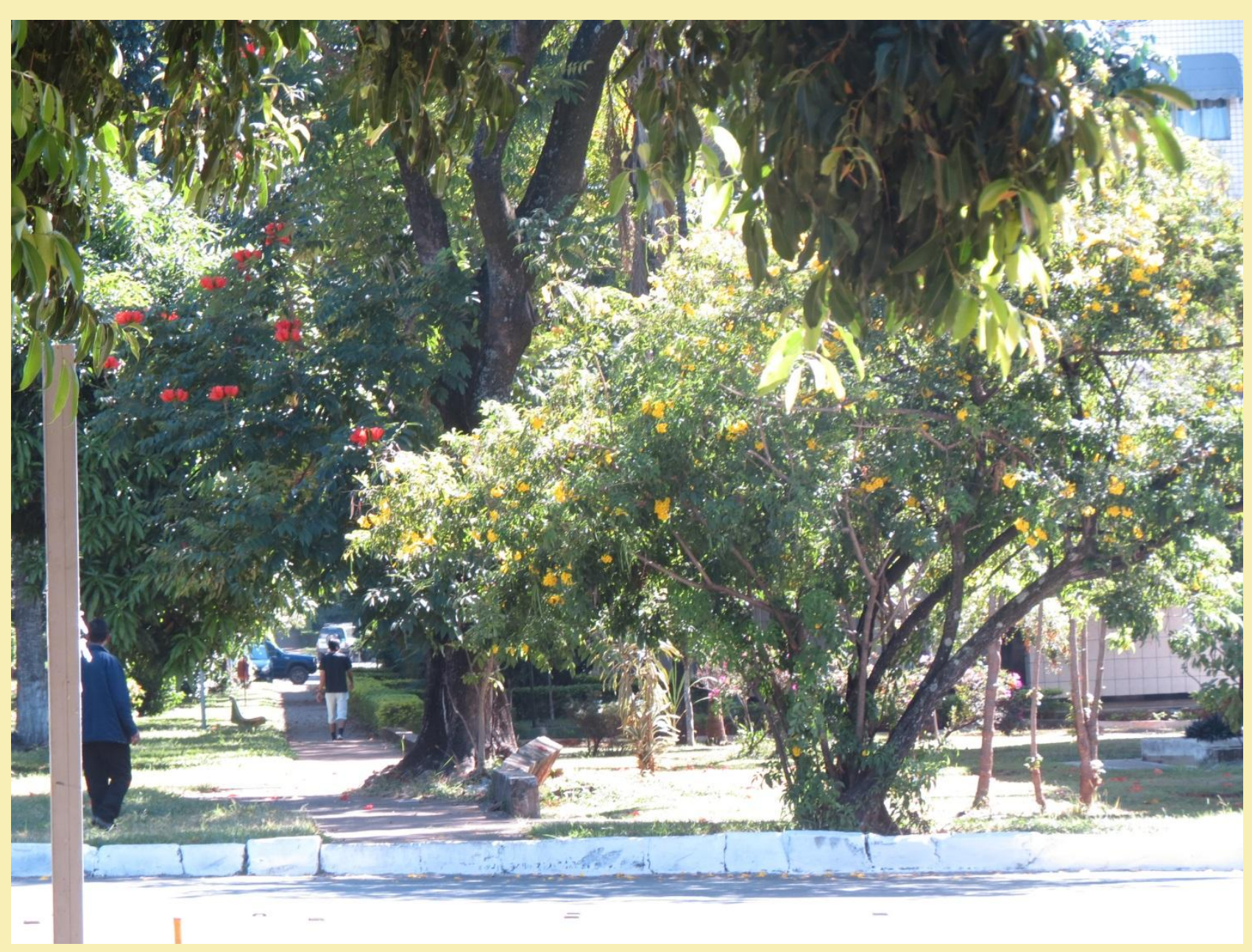




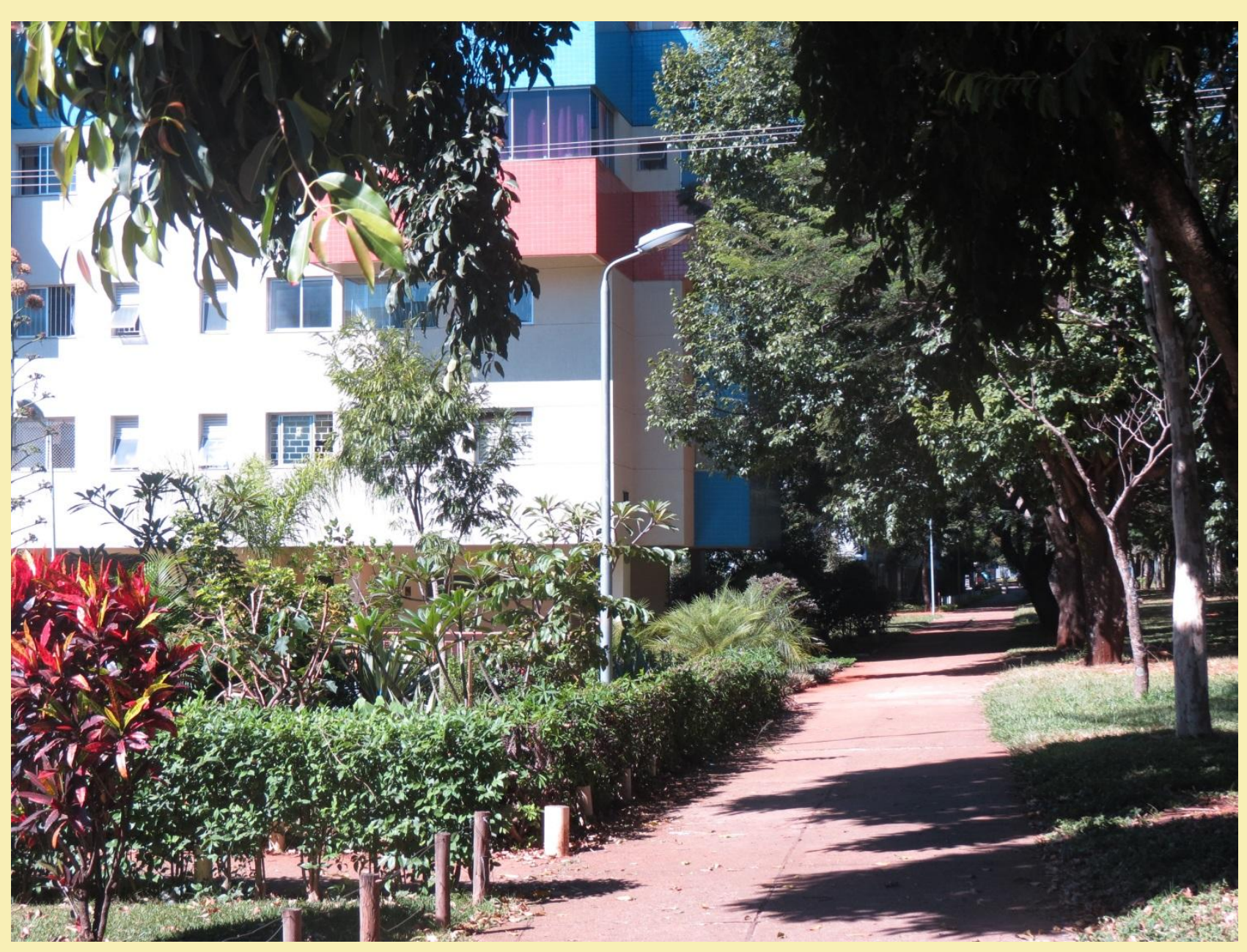




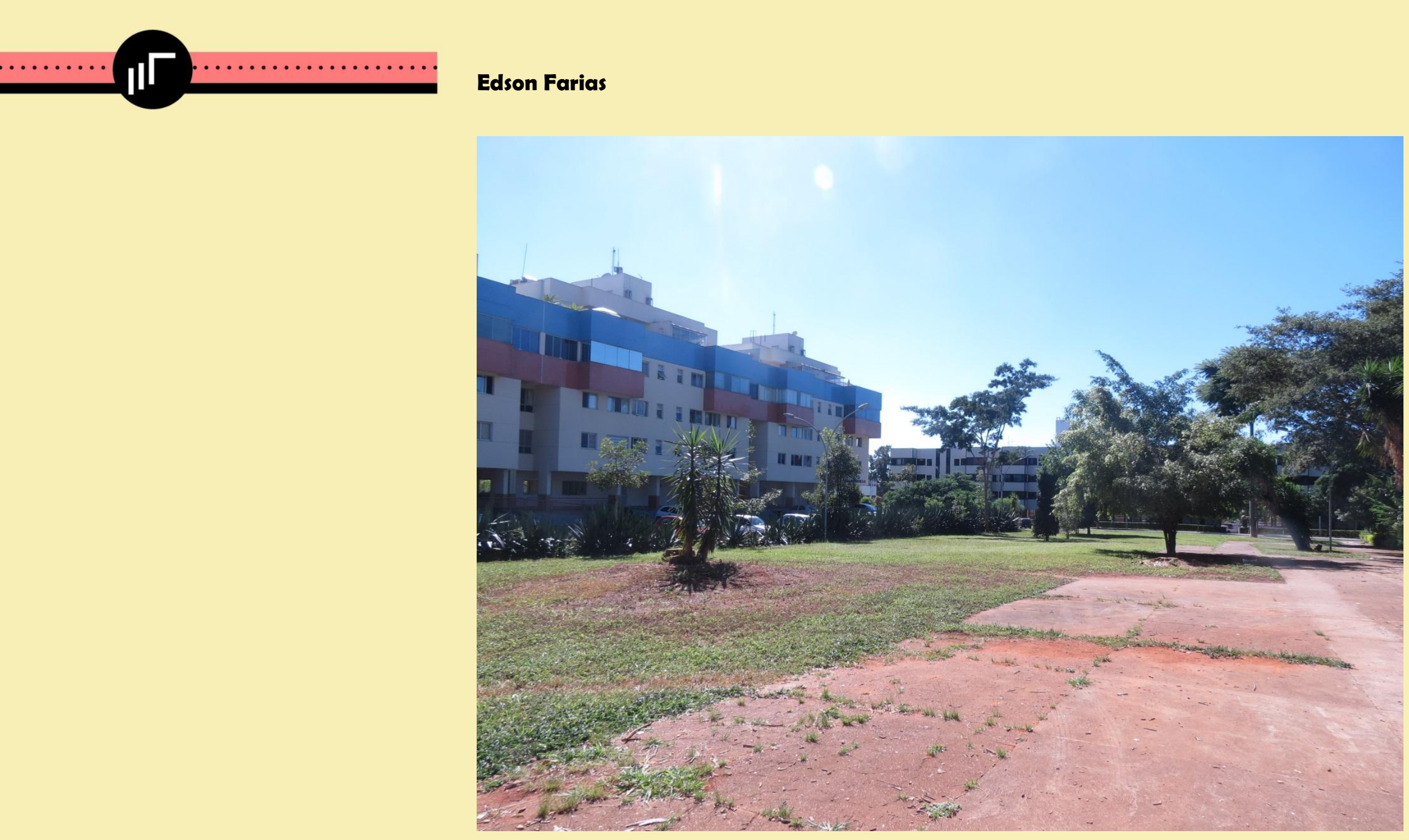




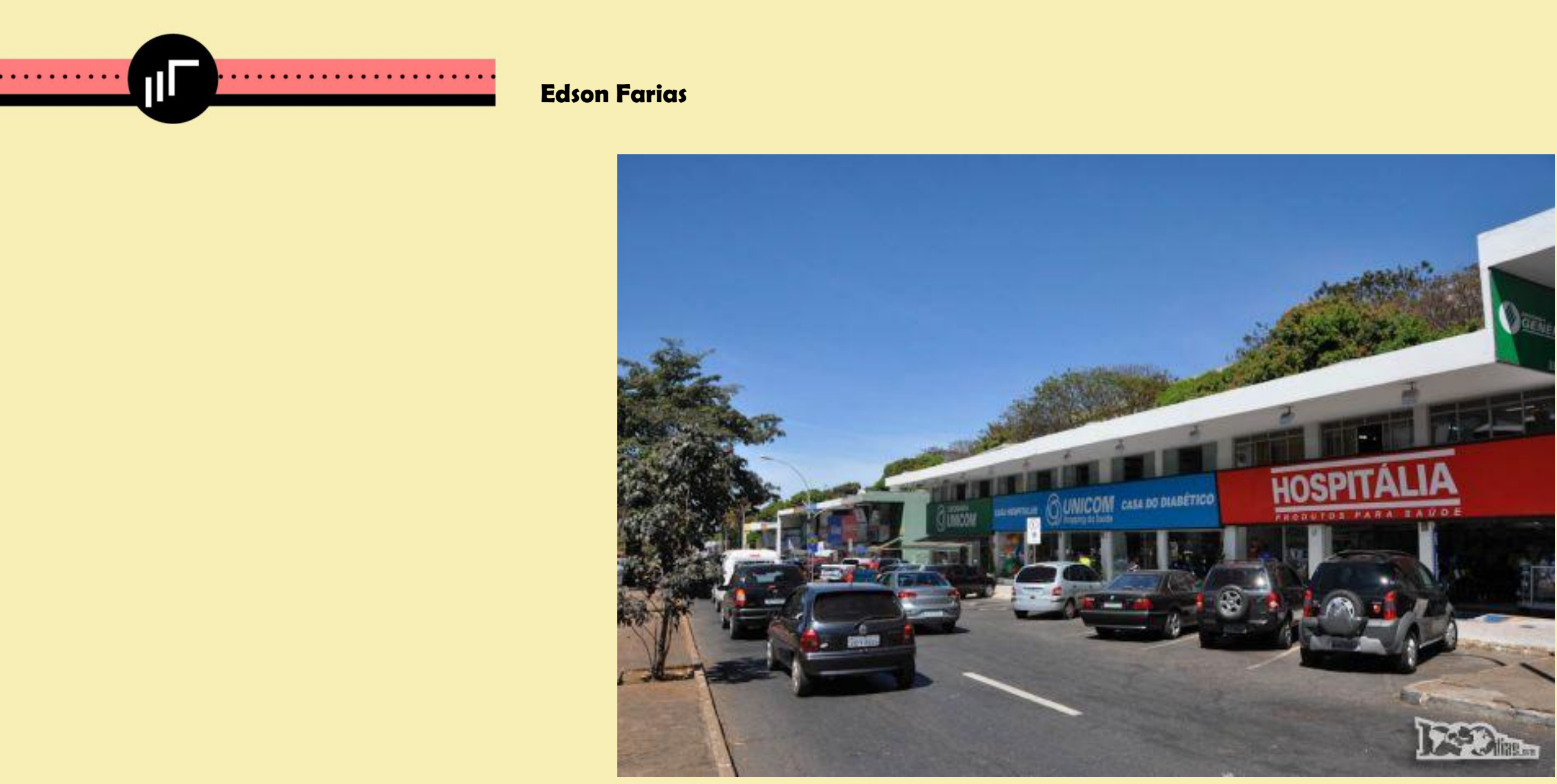




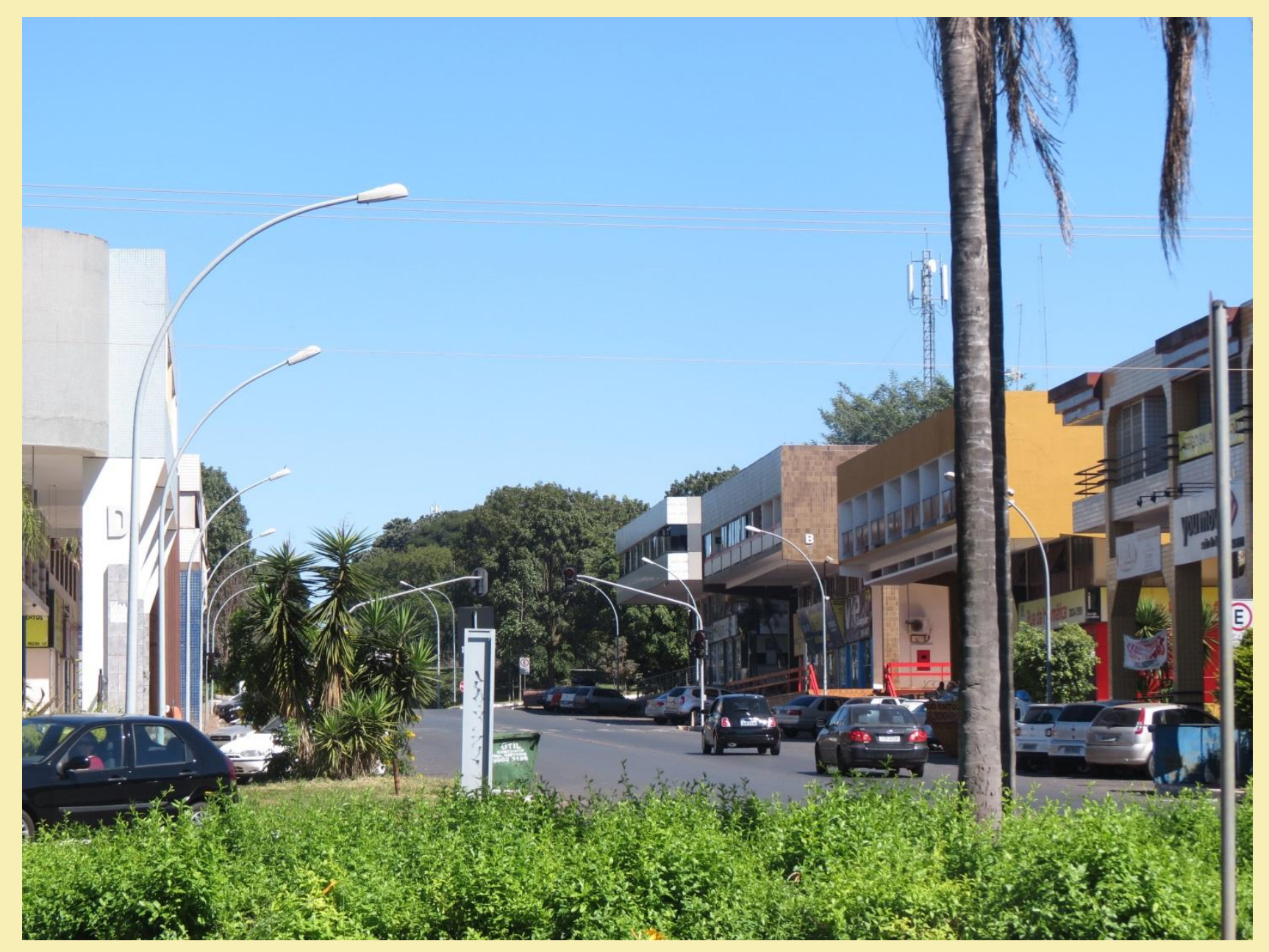




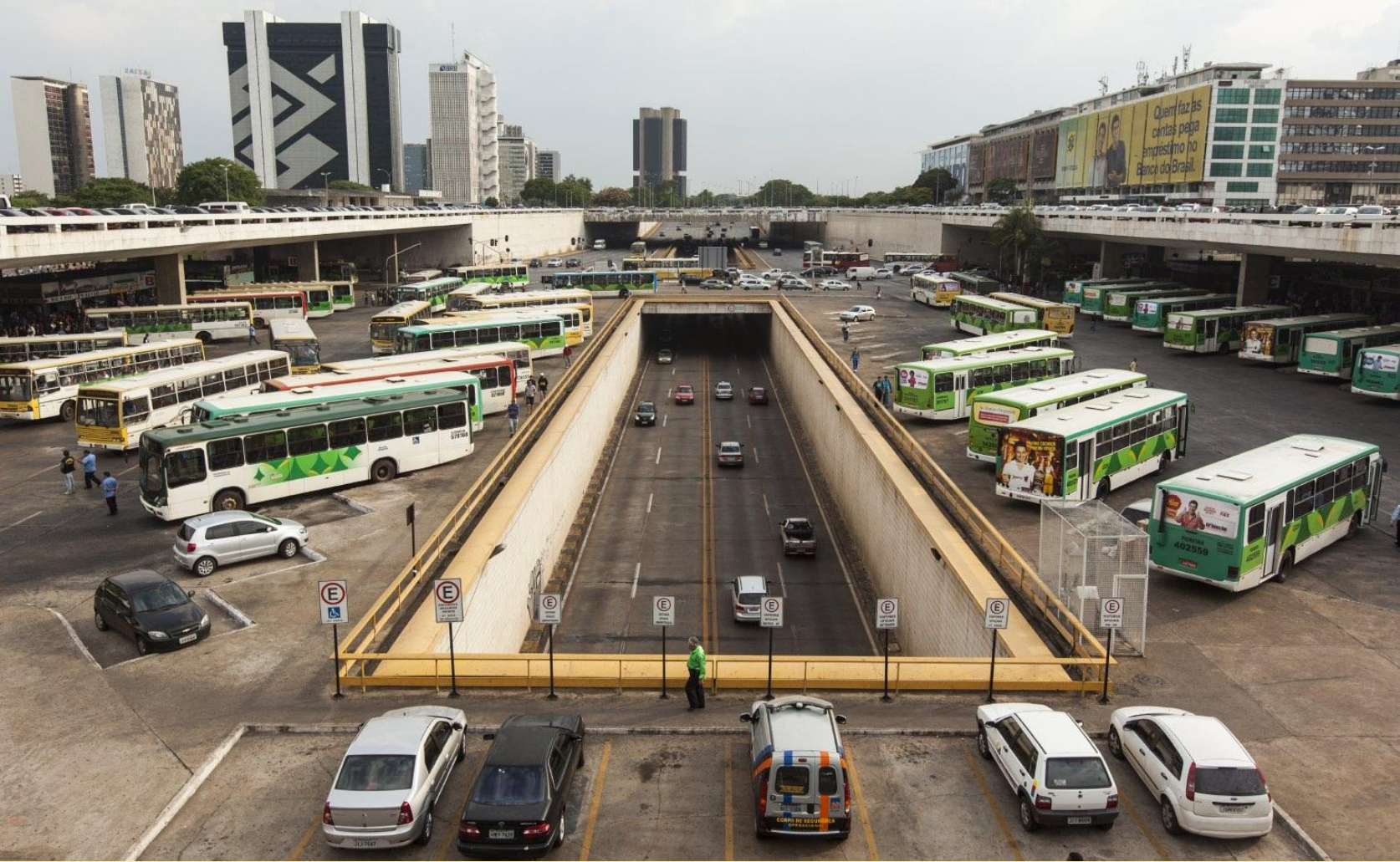




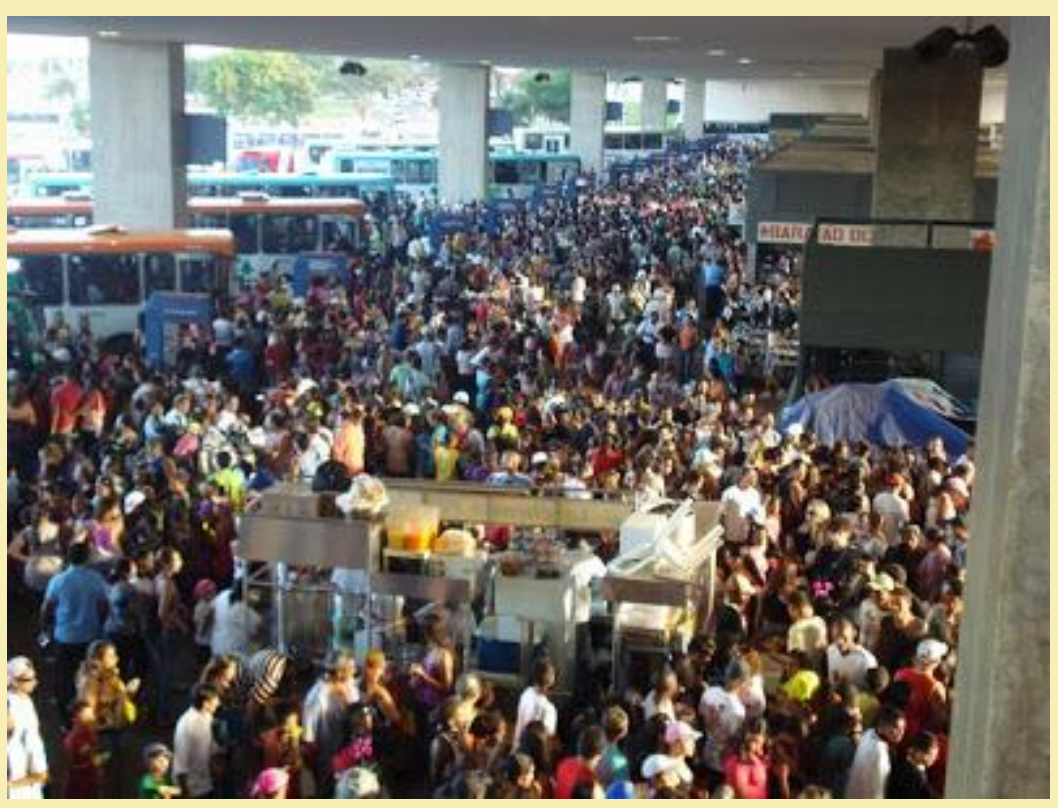

El objeto de conocimiento de nuestra investigación se delimitó en la medida en que elegimos el Plano Piloto en un marco cognitivo y normativo con implicaciones para los posibles usos del espacio urbano en el Distrito Federal.

nte, a los marcos del entendimiento humano. Pero en nuestra investigación el concepto está relacionado con los procesos sociohistóricos de estructuración de los símbolos de la comunicación y orientación de los actos.
Nuestra propuesta era inferir el grado de la centralidad del Plano Piloto en la regulación de los usos del contexto metropolitano. Centralidad geopolítica, cognitivo y moral, hasta el punto de ocupar la posición de un a priori histórico. La idea de a priori se refiere, usualme

Dividida en dos planos - una reconstrucción histórica y genealógica y otra cartográfica, centrándose en los usos -, la investigación tomó dos direcciones paralelas. Así, por un lado, hicimos una reconstrucción histórico-social con el objetivo de observar tanto los 


\section{Edson Farias}

factores que interfieren en el cambio de la sede del gobierno central de Río de Janeiro hasta el interior, así como la intersección entre la nueva capital que se propone y el modernismo estético.

La otra parte se dividió en dos momentos. En primera instancia, hemos creado cinco grupos de focales con personas de diferentes zonas del contexto metropolitano de Brasilia. En estas ocasiones, además del criterio socio-espacial en el reclutamiento de seis participantes, consideramos la estratificación por niveles de edad, género y educación.

En cada sección de los grupos de focales, donde nos proyectábamos imágenes de diferentes regiones del contexto metropolitano, se pidió a los participantes que las relacionaran con imágenes del Plano Piloto, que se presentaron al final. El objetivo era observar cómo, en las declaraciones de las personas, se han relacionado los sentidos de los lugares y los órdenes urbanos.

Los resultados de la realización de los grupos focales fueron la confirmación de nuestra sospecha respecto a la decisiva importancia del Plano Piloto en la orientación cognitiva y normativa de los comportamientos socio-espaciales en Brasilia y sus alrededores.

Todas las discusiones fueron grabadas y posteriormente sirvieron para que equipo de investigación definiera en qué aspectos

Dossiê Expressões Artísticas e Mulheres

Arquivos do CMD, Volume 2, N. 2. Jul/Dez 2014 deberían centrarse las cartografías de los usos del contexto metropolitano brasiliense. A los siguientes puntos se les dió prioridad: El trabajo, la movilidad urbana, la alimentación, la vivienda, la cultura, la educación y la colonización. Luego, cada miembro del equipo le dedicó un año en el aspecto de investigación elegido por él. Y tenía la libertad de decidir a cómo podría cuestionar el punto elegido. Pero siempre teniendo en cuenta las formas sociales en que las perspectivas de la homogeneidad y la diversidad se cruzarían en los usos del espacio brasiliense.

La combinación entre los resultados de las dos partes que organizaron la ejecución del proyecto de investigación llevó a las tres siguientes proposiciones:

a) Brasilia es la realización de la unión entre la utopía y la ideología de la modernización compartidas en un campo de poder inseparables de las asignaciones históricas de la modernidad y de la estructura industrial urbana y servicios en Brasil;

b) Las racionalizaciones sociales y culturales asistieron al principio de transparencia y de la dominación racional interna del conjunto modernista arquitectónico y urbanista. En este sentido, eran la contrapartida de las presunciones funcionales para prescribir el desempeño de las agencias, además de modelar escenarios de 
una propagación dinámica entre la segunda mitad del siglo XIX y

actuaciones;

c) En el periodo posterior a la instalación de la nueva capital se produjo la propagación de diversidades étnicas e históricas como estilos y formas de vida que, aparte de saturar, insiere ambigüedades, ambivalencias simbólico-expresivas y polisemias éticas y morales en los usos del contexto urbano-metropolitano brasiliense. Todo ello opera en contra de la perspectiva de la sociedad uniforme, de acuerdo con la versión republicana del Estado-nación.

Así, cuando entitulamos el libro que contiene los resultados de la investigación como "Líneas que se extienden en las curvas" hemos querido destacar la intimidad existente entre la utopía de la transparencia y el control racional con sus vicisitudes históricas, en el contexto metropolitano de Brasilia. Vicisitudes que no permiten comprobar los privilegios de esa utopía. Al mismo tiempo, las mismas diversidades actualizan el compromiso con la planificación.

\section{¿Qué hay en el utopía brasiliense?}

Sin lugar a dudas, el diseño y la construcción de Brasilia estaban en el mismo flujo de las reformas parisinas, lideradas por Haussman. Reformas urbanas que se habían convertido en un tipo de parámetro de Dossiê Expressões Artísticas e Mulheres principios del siglo $\mathrm{XX}$, donde se produjeron grandes cambios en Glasgow, en New York, Buenos Aires, Santiago y Río de Janeiro, entre otras ciudades.

Al mismo tiempo, también es cierto que Washington y Canberra han anticipado la decisión de trasladar la capital nacional al interior de sus países. Así como Brasilia, a ambas experiencias correspondía construir centros urbanos destinados sólo para las funciones políticas y administrativas.

Pero el traslado del centro político y administrativo para e interior se asocia directamente con la formación del Estado-nación en Brasil.

A mediados de 1810, en su Projeto para o Brasil, José Bonifácio enumeraba el traslado de la capital, junto a la abolición de la esclavitud y la industrialización, como condiciones básicas para el desarrollo y la emancipación nacional. Vale la pena recordar que, aparte de "Patriarca de la Independencia", Bonifácio recibió la responsabilidad tutorial de pequeño emperador Pedro II a la partida de su padre, Pedro I, después que abdicó del trono brasileño y regresó a Europa. 


\section{Edson Farias}

Durante el Segundo Imperio de Brasil, en la segunda mitad del siglo XIX, las propuestas y los debates sobre la construcción y el traslado de la capital salieron a la luz y también se abandonaron. Sin embargo, es cierto que los debates dejaron por herencia el viaje de la misión de reconocimiento liderada por el agregado diplomático e historiador Francisco Adolfo de Varnhagen (Visconde de Porto Seguro) hasta la Meseta Central, donde hoy se ubica Brasilia.

El legado de esta misión sólo se reanudó con el paso de la monarquía a la república, a fines del mismo siglo XIX. En este momento los efectos de la guerra contra el Paraguay en la formación de nuevas élites militares en conjunto con la inserción de cuadros políticos de las clases medias urbanas vitorearon propuestas orientadas a la plena integración nacional y su desarrollo industrial. Bajo este ambiente el Congreso Nacional Constituyente votó y aprobó, en 1891, el traslado de la capital a la Meseta Central. Esto llevó a la separación de una zona del Estado de Goiás, destinada a la realización del trabajo.

Durante los gobiernos militares de Deodoro da Fonseca y Floriano Peixoto, se envían dos misiones militares y científicas a esta zona. Ambos fueron ordenados por el astrónomo belga Louis Cruls. La tarea de estas misiones era llevar a cabo estudios más profundizados para subsidiar la construcción de la nueva ciudad.
En los años siguientes, sin embargo, volvieron al poder los mismos segmentos terratenientes oligárquicos comprometidos con la exportación de productos agrícolas. Así que se encuentran retrasos en la transferencia de la capital y hubieron retrocesos sensibles en esfuerzos por industrializar el país.

En los cincuenta años subsecuentes, Brasil sufre fuertes transformaciones socio-estructurales. Poco a poco, la industrialización y la expansión del tejido urbano suplantan la centralidad de los medios de vida rurales. Los segmentos sociales urbanos adquieren cada vez más repercusiones culturales y políticas. En la década de 1920, los modernismos estético, científico y político son las manifestaciones por excelencia del ascenso de estos grupos en la jerarquía social. La reunión de estas tres facetas en el mismo campo de poder se produjo so después de 1930. El Movimiento 1930 derrocó la oligarquía cafetalera y llevo hacia al poder nacional las facciones de ex militares, representantes del modernismo político de la década de 1920. Así, comienza a dictadura civil encabezada por Getúlio Vargas durante 15 años.

A pesar de las fluctuaciones políticas del gobierno Getúlio Vargas, el periodo que comienza retrae el poder de los grandes terratenientes. Al mismo tiempo, muchas voces se alzaron en torno a los problemas heredados de la época colonial, discutiendo sus efectos sobre 


\section{Edson Farias}

el presente y futuro de Brasil. Los diagnósticos condujeron a la necesidad de integrar el país. La cuestión de la identidad del pueblo brasileño también adquirió el estatus de un problema nacional. Es decir, ¿cuál sería el ser social brasileño original?

Entre las distintas posibilidades, la que obtuvo el mayor éxito fue la formación discursiva que perfila la cultura y la identidad brasileña por el mestizaje étnico.

Con esto, vemos en esta formación discursiva la imagen del mestizo brasileño heredero de la intersección de blancos, negros e indios. Más importante, esta fórmula discursiva pone el énfasis en la tolerancia y por lo tanto favorece el tránsito, sobre todo entre el pasado y el presente. Se destaca la propensión de Brasil a unir el barroco colonial a la máquina; la concepción del primitivismo de la percusión a la intensidad veloz de la vida metropolitana. La promesa de la novedad entendió el encuentro dialéctico entre lo antiguo y lo más actual. En síntesis, la modernidad brasileña introduciría esta unidad en la civilización.

La trama de todos estos discursos generó el mito nacional del Brasil "moderno". Como cualquier mito, comprende un auto-referencia narrativa capaz de superar las contradicciones, en este caso, socioDossiê Expressões Artísticas e Mulheres

Arquivos do CMD, Volume 2, N. 2. Jul/Dez 2014
Con el fin de la Segunda Guerra Mundial y el retorno del país a las órdenes de un gobierno elegido por el voto directo, el aumento de la población y el crecimiento económico que acompañó a la industrialización, impusieron la cuestión del lugar de Brasil a nivel internacional. Después de permanecer cerrado en sí mismo durante el dominio colonial portugués, adquiriendo características de una especie de "Oriente" americano. La sociedad esclavista se ha mantenido en la base del tráfico humano y de las plantations. A lo largo del siglo XIX y hasta inicios del siglo XX, la posición de Brasil en las Américas fue insignificante, a pesar de sus proporciones geográficas.

Ante esta situación, la década de 1950 fue, al mismo tiempo, una confluencia de ideas y posiciones adoptadas como también la inflexión acerca del futuro de Brasil. Un proyecto nacional surgió: la arquitectura musical de la bossa nova y las huellas de Brasilia fueron su núcleo.

La materialidad de la nueva capital hizo visible la promesa de la novedad brasileña presentada en el mito del Brasil moderno. Al mismo tiempo, en sus contornos se materializaron las aspiraciones de un Estado-nación originario de las condiciones de dependencia colonial y también se han previsto los imperativos de control estatal sobre el vasto interior del país. En este sentido, parece razonable proponer que Brasilia representa la realización de una utopía estatal. 


\section{Edson Farias}

El paisaje urbano del Plano Piloto de Brasilia celebra la aplicación de la ciencia del urbanismo en el control de las incertidumbres naturales e incluso sociales. Además, en la medida en que se compone de líneas de coordenadas, dirigidas a la transparencia total de un territorio y al movimiento fácil y rápido en una superficie, su diseño miniaturiza el propio Estado. Es decir, es como si las pretensiones de control y centralización del Estado nación se llevaran a cabo en esa ciudad-Estado. Ahora, en el centro del país - el "corazón" - todas las miradas convergen en la sede del poder y desde ésta se pueden emitir sus miradas al conjunto brasileño.

\section{Polisemias de un ícono}

En el momento en que se hace, la utopía de Brasilia se convirtió en un signo. Signo de la inventiva del pueblo brasileño apoyado en la fuerza y en la competencia del Estado para reclutar los medios a fin de promover el desarrollo, la soberanía y la seguridad nacional.

Pertenece al signo expresar y comunicar lo que no está presente. Cuando un signo, por sus características visuales, se confunde con su referencia lo llamamos icono.

La monumentalidad de Brasilia es un icono de la nación, pero la transfiguración de la nación en un genio arquitectónico: el de Oscar
Niemeyer. Así como la epopeya de la historia nacional se transfigura en el heroísmo político de Juscelino Kubitschek - presidente de la República responsable de la construcción de la nueva capital. El icono muestra la nación y su historia, pero desde la perspectiva del campo de poder que la hizo posible.

Sin pretender menospreciar o negar esta versión de la historia de Brasilia, es posible introducir otra que corre paralelo e incluso transversalmente.

El traslado de la capital al interior tuvo lugar en el mismo momento en que se aceleró el cambio en la población del campo a la ciudad. En cincuenta años, Brasil ha pasado de ser un país eminentemente rural para una situación en la que más del $80 \%$ de la sociedad vive en áreas urbanas.

En el inicio, el éxodo fue exportado a la región Centro-Sul. Con la inauguración de Brasilia, poco a poco una parte importante de la gente caminó hacia el oeste. La mayoría de los migrantes provenía de zonas de la región Nordeste.

Las personas con baja escolaridad y sin la preparación para el ejercicio de las funciones urbanas más cualificadas se sintieron atraídas 


\section{Edson Farias}

por las posibilidades de encontrar formas de vida durante la construcción del capital. Las olas humanas que siguieron tenían las mismas características. Muchas de esas personas encontraron empleos en servicios informales a la burocracia del gobierno instalado en el Plano Piloto.

Intervención paternalista del clientelismo político, había muchas familias que tenían acceso a pequeñas parcelas de tierra donde construyeron sus casas. Por supuesto, sin acceso a la legalización de la propiedad. Como es común en este tipo de experimentos, el ajuste de un miembro de la familia sirve como un estímulo para el desplazamiento de los nuevos migrantes.

Una de las consecuencias de la aplicación de esta política informal de colonización fue el dramático aumento en la población del Distrito Federal: que supera en poco tiempo la predicción de que la cantidad de la población se limitaría a 500000 habitantes.

El crecimiento de la población, sin embargo, no alteró significativamente la estratificación socio-espacial que prevaleció en el Distrito Federal desde su fundación. Separado por un inmenso vacío territorial, la zona del Plano Piloto permaneció aislada de las ciudadessatélites donde se centraban sobre todo estos grupos de migrantes. Las políticas de eliminación de viviendas irregulares en las inmediaciones del Dossiê Expressões Artísticas e Mulheres
Plano Piloto, implementadas por el gobierno local, promovió aún más esta concentración de migrantes pobres en las ciudades-satélites.

En 1969, nueve años después de su fundación, Brasilia tenía 79.128 habitantes que vivían en los barrios pobres, formados por 14.607 chozas. La población del Distrito Federal había llegado a 500000 habitantes.

La fundación de la ciudad satélite de Ceilândia, entonces, es un ejemplo de los episodios que marcaron el otro lado del despliegue de Brasilia. Esto se debe a los escenarios y paisajes urbanos distantes geográfica, social y culturalmente de los rasgos modernistas del Plano Piloto, al tiempo que componiendo también el Distrito Federal.

Como resultado de las iniciativas de transferencia de poblaciones que ocupan áreas irregulares, Ceilândia pronto se convirtió en la zona más poblada del Distrito Federal. El cambio gradual de las precarias condiciones de vida para las maneras más regulares se alió con la recreación de las costumbres relacionadas con las regiones de origen de los grupos de migrantes. Por lo tanto, los hábitos alimentarios y los gustos musicales, aun las prácticas educativas e también las fórmulas directas para la resolución de 
conflictos intersubjetivos y sociabilidades recriaran en las experiencias fuertes características de recuerdos rurales. Su feria es otro icono, pero allí hay un distrito federal, donde la nación recibe muchos colores y se le rompe la cara en una variedad de rostros.

Imágenes: Ceilândia en meados de los anos de 1960 y

hoy

Dossiê Expressões Artísticas e Mulheres

Arquivos do CMD, Volume 2, N. 2. Jul/Dez 2014 


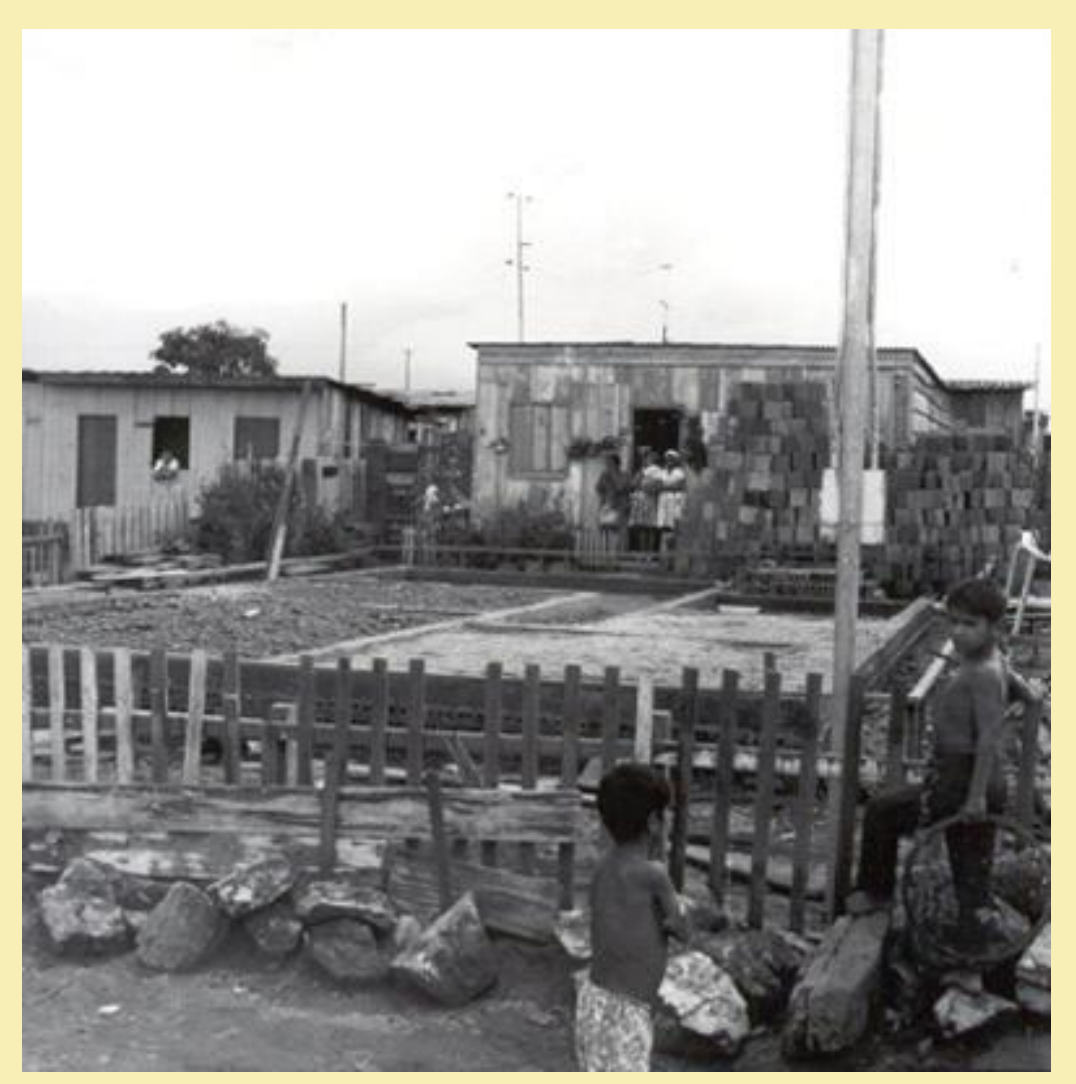




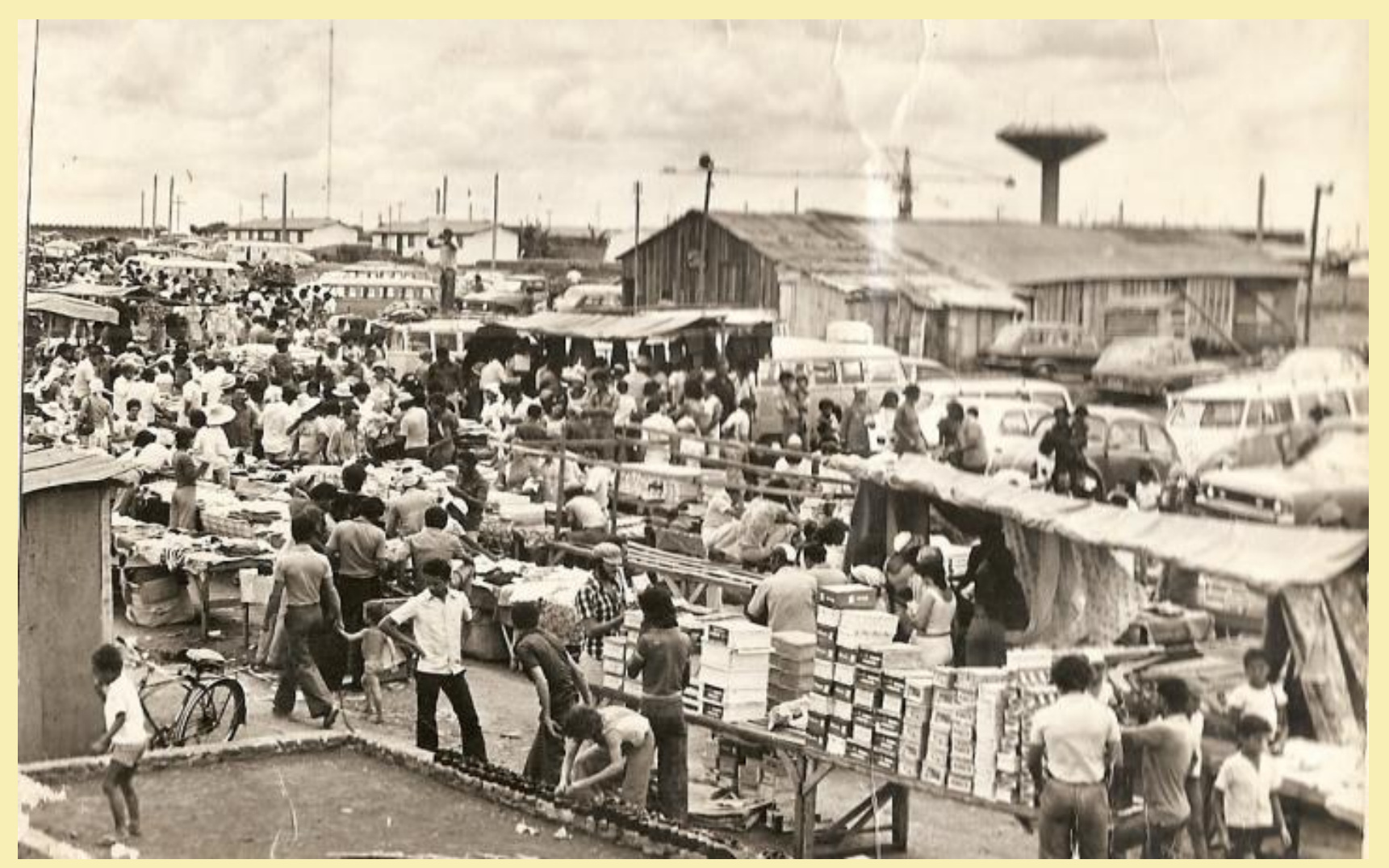




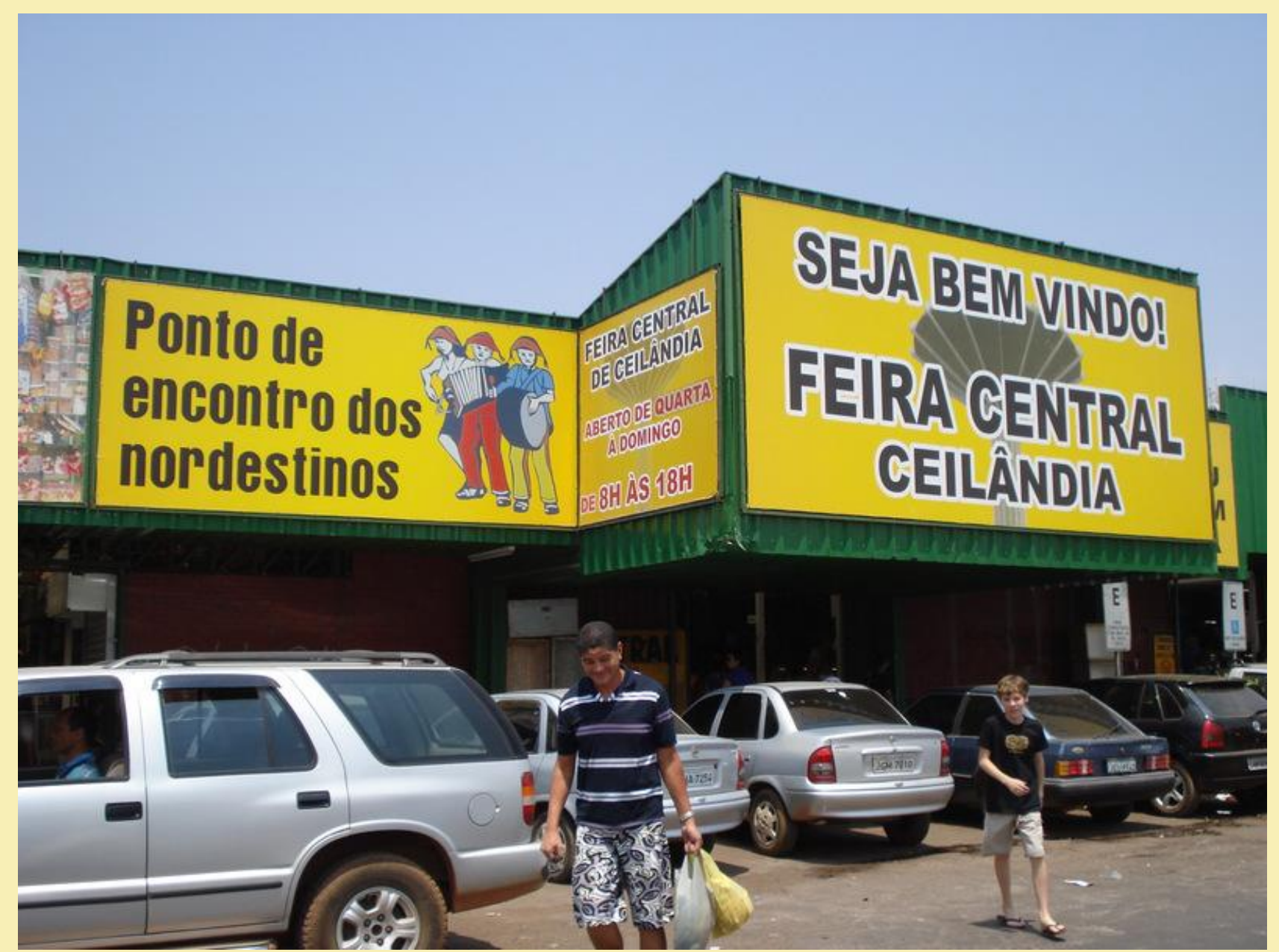




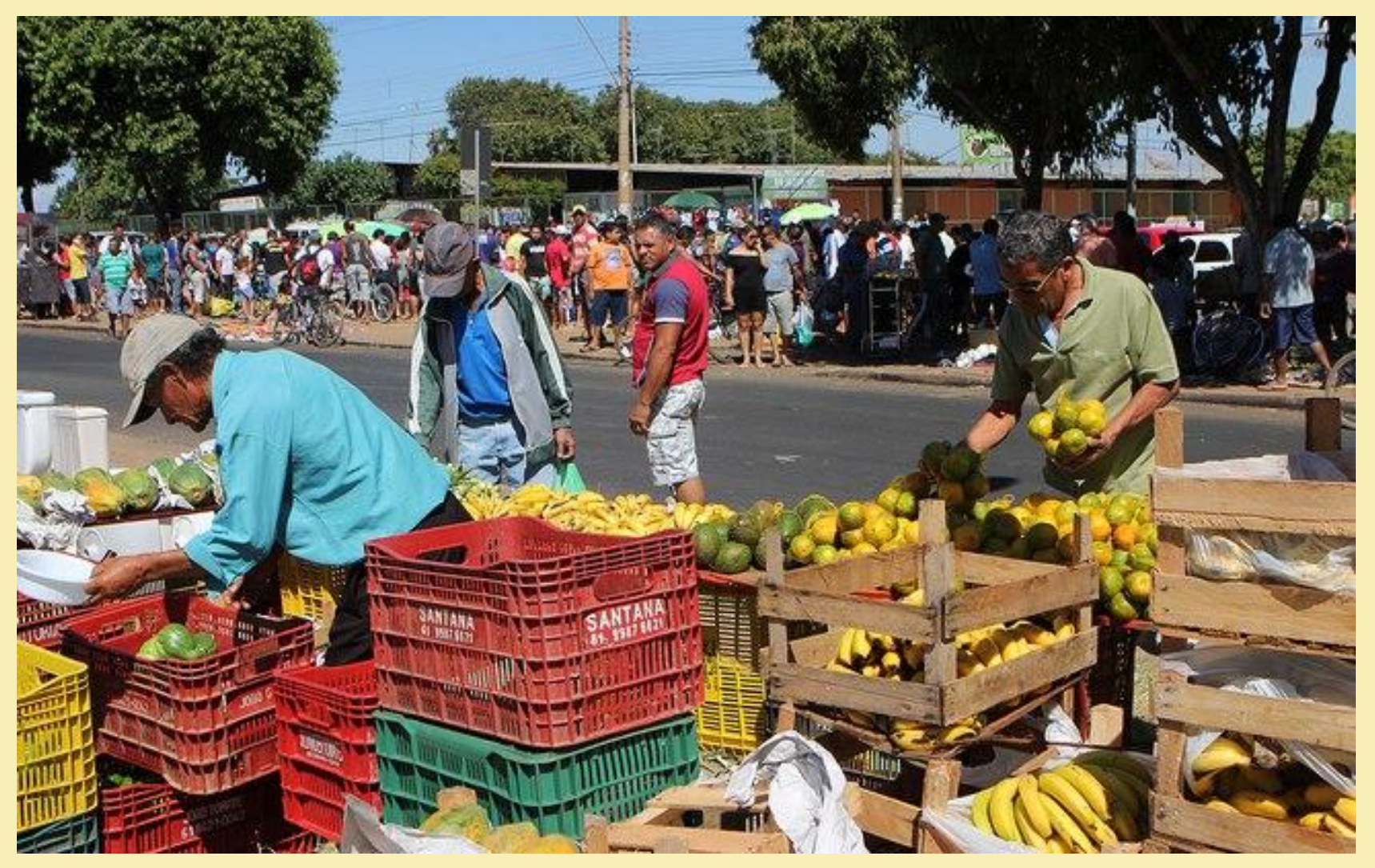




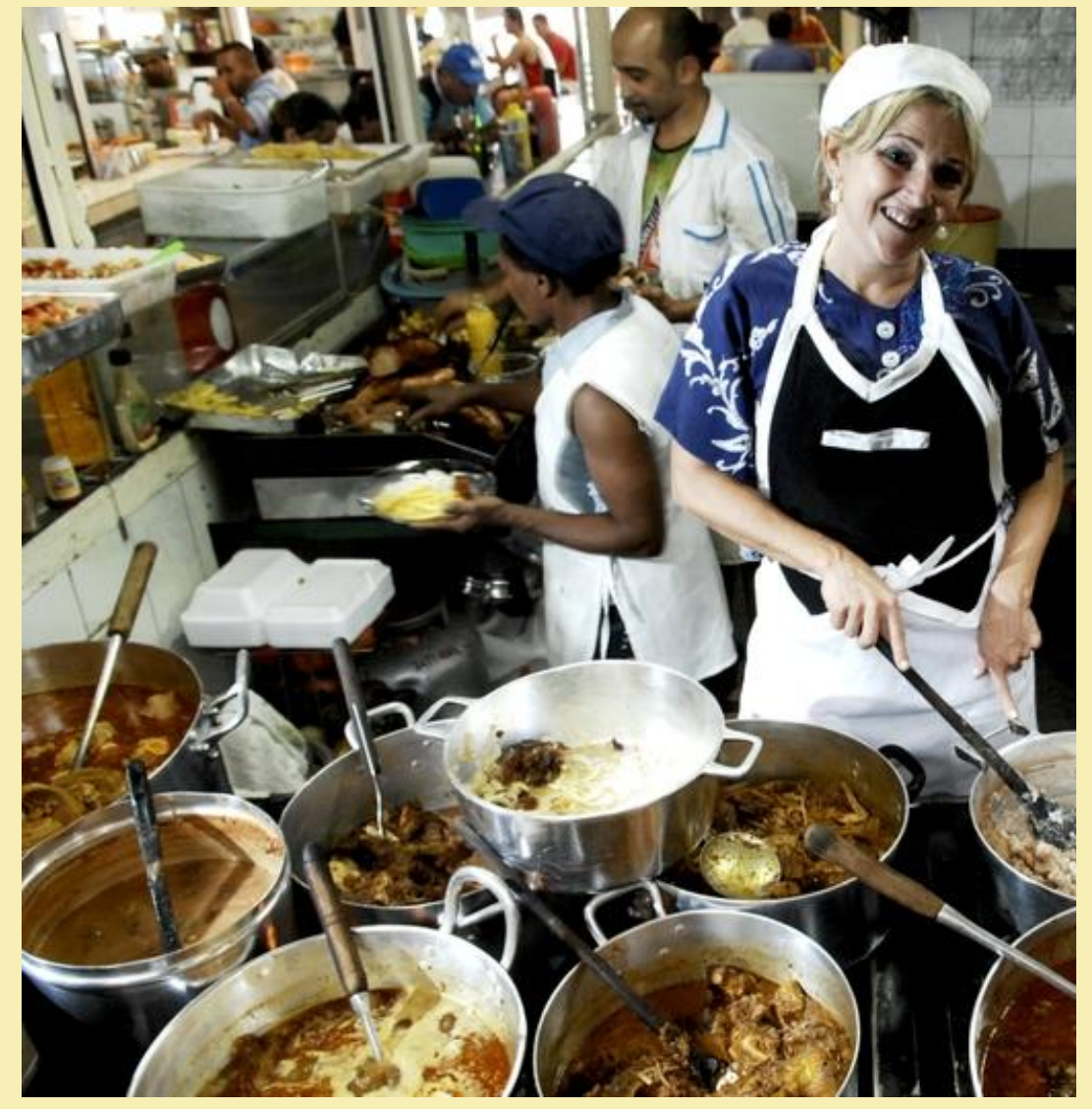

Ubicado en una zona de expansión de la frontera, el Distrito Federal se convirtió en campo de las acciones de especuladores inmobiliarios y apropiación fraudulenta de tierras. Ambas actuaciones contribuyeron a que la ocupación urbana avanzara más hasta las ciudades fronterizas del Distrito Federal. También contribuyeron las donaciones electoralistas de propiedades de tierras promovidas por el clientelismo político.

El saldo de esta triangulación entre la migración intensa, el clientelismo político y el comercio ilegal de la tierra se manifiesta en la expansión urbana pulverizada que ahora define el contexto metropolitano brasiliense.

Esta expansión de la población en un territorio no fue acompañada por el aumento de los medios de transporte. Reducida a la red de carreteras, la movilidad urbana estratificó dos grupos bien distintos. Por un lado, los que circulan en vehículos particulares. Por el otro, los pasajeros de la micro. Estos últimos son los que han sido sometidos a la precariedad de los servicios prestados por un oligopolio de empresas. Las líneas de metro quedan muy por detrás de las demandas

La dinámica socio-histórica que adquiere poder e intensidad en Brasil después de la dictadura militar dejó atrás el sueño de la modernidad por la que cambió los esfuerzos para promover la construcción de utopía brasiliense. La expansión del tejido urbano en alianza con el montaje de un parque industrial importante no necesariamente han llevado a pique a las identidades de las regiones y los regionalismos. Ambos se actualizan en complicidad con la expansión de la parafernalia institucional del Estado- 
nacional. Es decir, las líneas de mando y control local y regional también modernizan y mantienen una historia de las propias conjunciones de poderes en Brasil: la unidad funcional tensa entre la centralización y la descentralización.

En los últimos años, la dinámica específica de esta modernización se ha redefinido. Cada vez más evidentes son los contornos de una estructura con una fuerte presencia de los servicios, especialmente los bancarios y de las finanzas. Pero la expansión de estos sectores está en consonancia con el tamaño de la exportación de productos agrícolas y la extracción de minerales en la formación del producto interno bruto.

En las últimas décadas, los requisitos funcionales del Estado brasileño se expandieron en la consideración de esta mayor complejidad en la sociedad nacional. Los cambios en el aparato estatal dejan su huella en el espacio de Brasilia. La presencia de funcionarios públicos en mayor número y de mayor cualificación presionó a los precios y tipos de propiedades que ofrece el mercado. También inserta nuevos patrones en el consumo de bienes y servicios.

Transformaciones que adquieren visibilidad socioespacial. Hay muchos ajustes: nuevos condominios ocupados por segmentos ricos de la sociedad que están aislados, por supuestos motivos de Dossiê Expressões Artísticas e Mulheres seguridad. Edificios altos de apartamentos que se diseminan y pululan en las regiones administrativas de Guara, Águas Claras, Samambaia, entre otras. Hay también propiedades buscando combinar las comodidades de la ciudad al paisaje campesino. Y cada vez más fileras de viviendas sencillas ocupadas por los trabajadores de bajos ingresos. En la década de 1980, muchos recolectores de basura, otros trabajadores con bajos salarios y pobres sin ocupación definida, ocuparon la zona alrededor del mayor vertedero de basura en el Distrito Federal, lo que genera un enorme barrio marginal (favela) a las márgenes de la Via Estrutural, una de las principales carreteras locales, cerca del Plano Piloto. Hoy asentamiento se denomina: la comunidad de la Ciudad Estrutural y está compuesta por 35.000 habitantes.

En todos estos ejemplos, el modelo de coordinar líneas del Plano Piloto, si no totalmente excluido, está mutilado.

La preservación del Plan Piloto, con su transformación en un sitio histórico nacional y la posterior elevación a la categoría de Patrimonio de la Humanidad, sigue siendo el centro de los debates. Si para muchos es una decisión irrevocable e indiscutible, hay otras voces que claman ser un obstáculo para el desarrollo socioeconómico del Distrito Federal mantener la mayor área preservada del mundo - 112,25 km². 
Sin embargo, la mirada en el paisaje urbano del Plano Piloto, hoy en día, parece no encontrar apoyo en estas oposiciones. Excepto para el sitio que cubre la Explanada de los Ministerios instalada allí, se encuentran usos espaciales que dejan en suspenso los criterios que guiaron la planificación y construcción de esa región. En los sectores bancarios y comerciales norte y sur, altos edificios emergen con fachadas de espejo con el fin de dar cabida a los centros comerciales, de prestación de servicios y negocios. Dentro de algunas de las super cuadras, destinadas a residencias, edificios que también emergen y tienen diseños distintos de la arquitectura modernista.

Podríamos añadir los usos que se hacen del espacio vendedores ambulantes, personas que cobran para cuidar de los coches aparcados en lugares públicos, propietarios de establecimientos comerciales, sobre todo bares y restaurantes. Las prácticas que alteran la visibilidad y la movilidad en esa zona.

Las numerosas funciones actuales en el Plano Piloto revelan la reunión y la confrontación de diferentes órdenes urbanos. Por lo tanto, muestran cómo la complejidad metropolitana actúa en el marco de ese espacio. El icono brasiliense se vuelve polisémico. El icono expresa y comunica algo más allá de la pretensión de homogeneidad de la nación republicana. 
Imágenes: Ciudades de Ceilância e Taguatinga

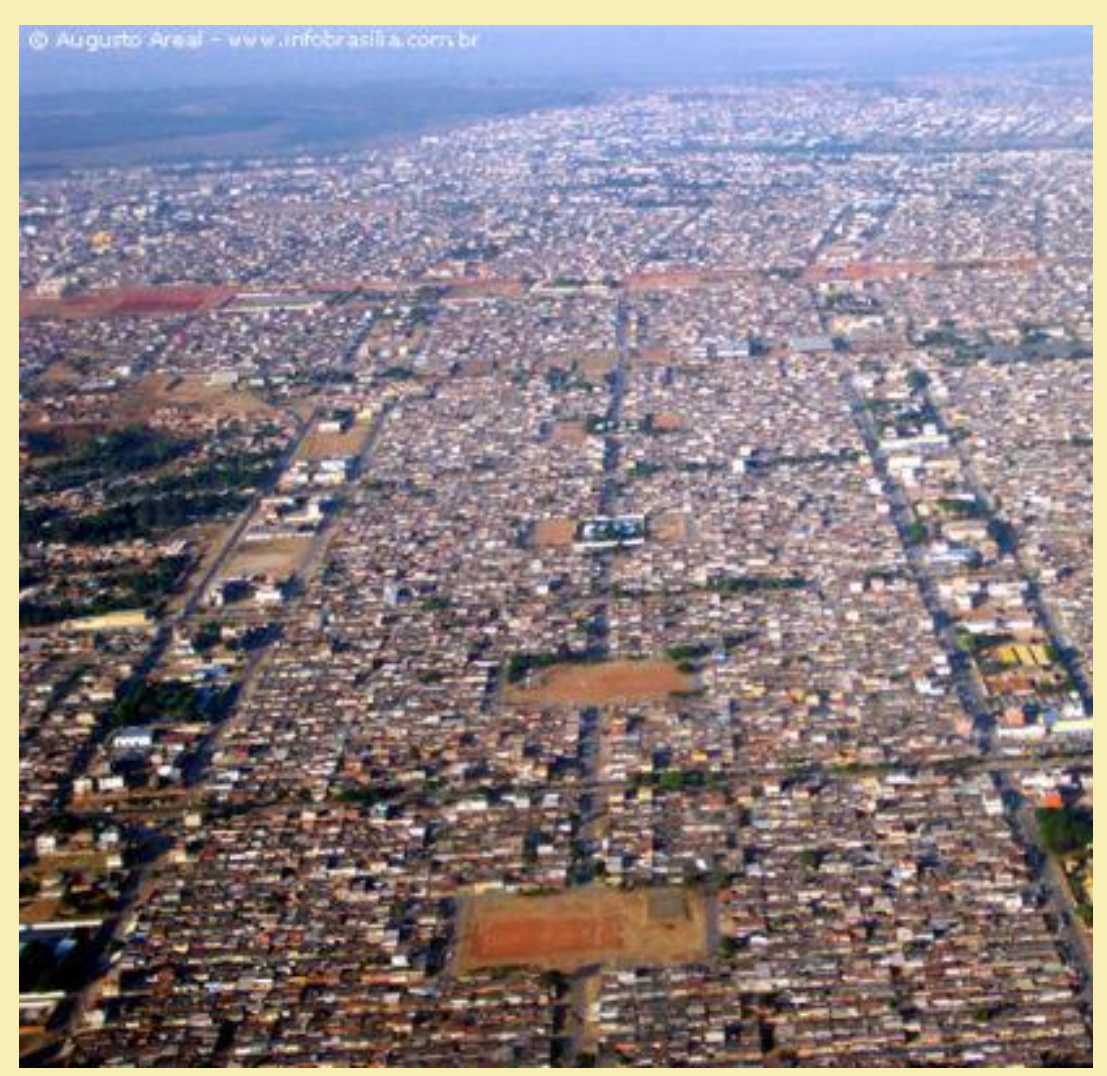

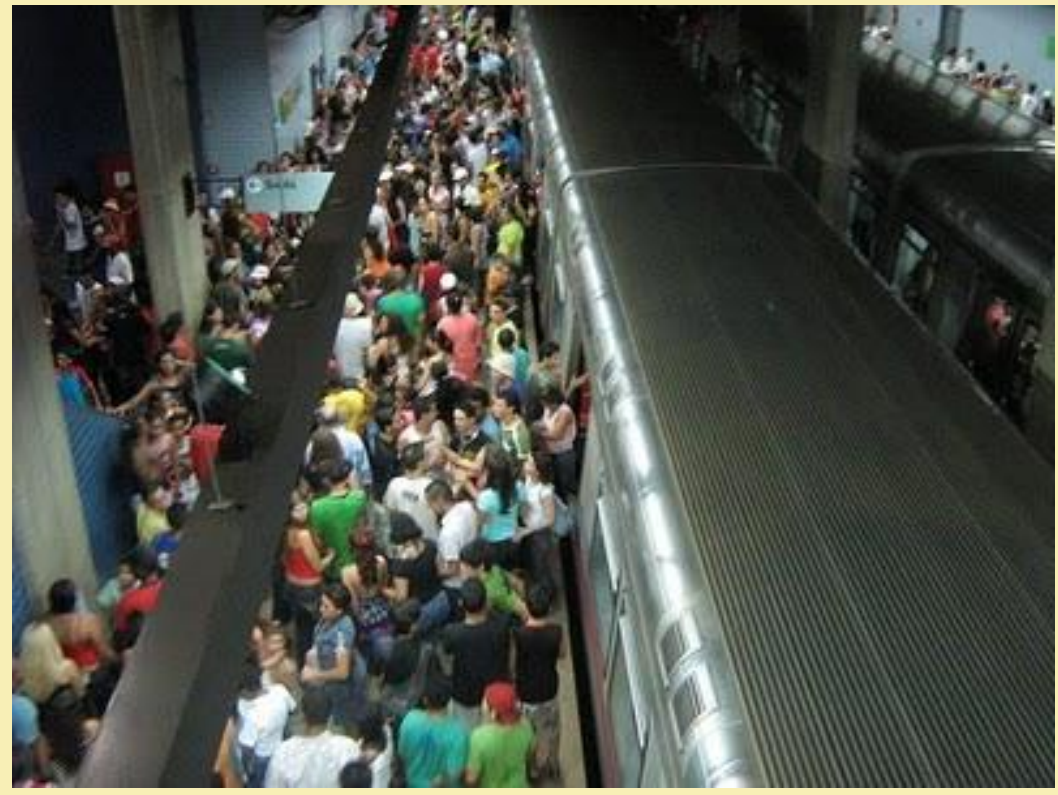




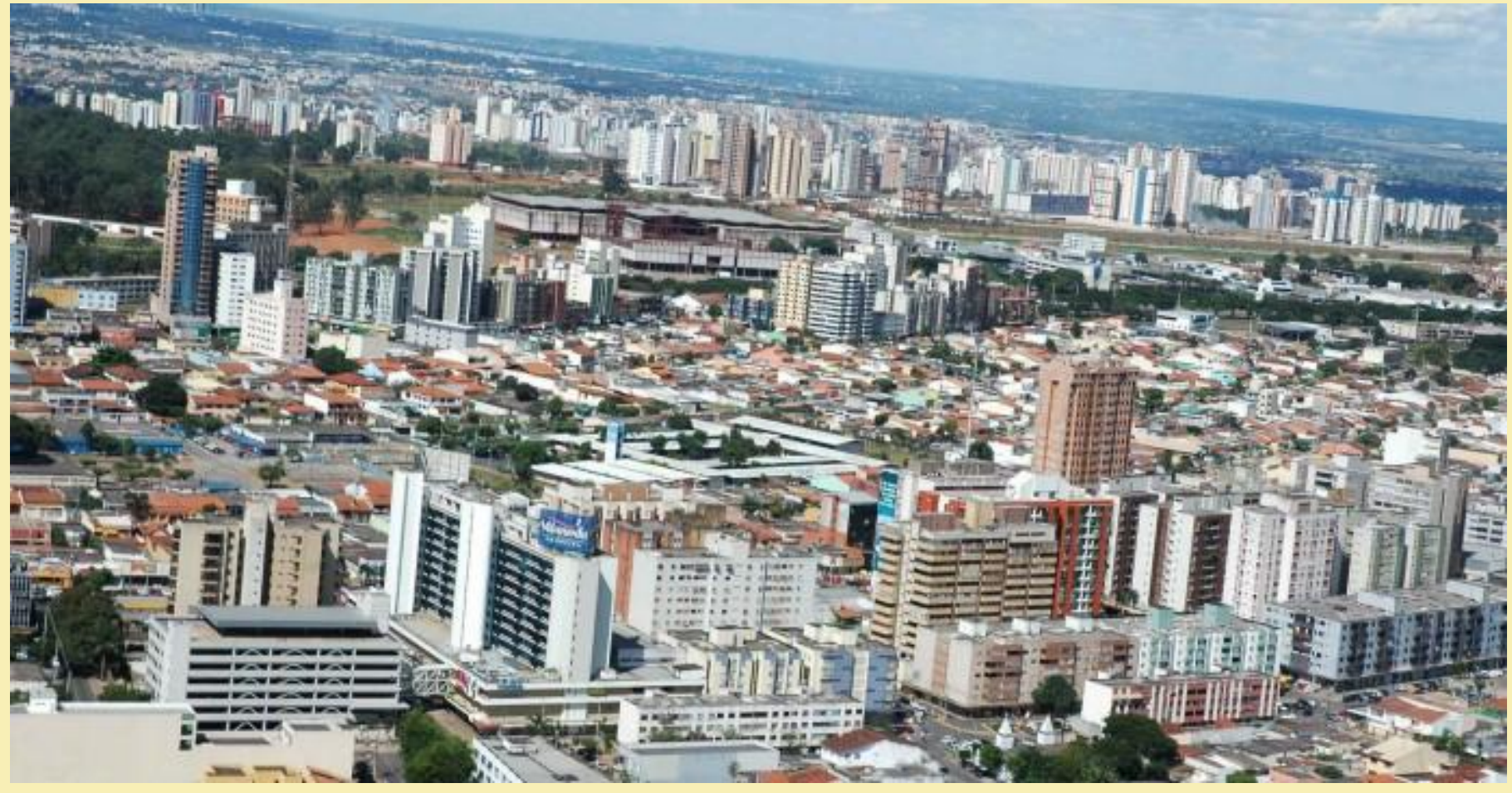

La preservación del Plan Piloto, con su transformación en un sitio histórico nacional y la posterior elevación a la categoría de Patrimonio de la Humanidad, sigue siendo el centro de los debates. Si para muchos es una decisión irrevocable e indiscutible, hay otras voces que claman ser un obstáculo para el desarrollo socioeconómico del Distrito Federal mantener la mayor área preservada del mundo - 112,25 km²
Sin embargo, la mirada en el paisaje urbano del Plano Piloto, hoy en día, parece no encontrar apoyo en estas oposiciones. Excepto para el sitio que cubre la Explanada de los Ministerios instalada allí, se encuentran usos espaciales que dejan en suspenso los criterios que guiaron la planificación y construcción de esa región. En los sectores bancarios y comerciales norte y sur, altos edificios emergen con fachadas de espejo con el fin de dar cabida a 
los centros comerciales, de prestación de servicios y negocios

Dentro de algunas de las super cuadras, destinadas a residencias, edificios que también emergen y tienen diseños distintos de la arquitectura modernista.

Podríamos añadir los usos que se hacen del espacio vendedores ambulantes, personas que cobran para cuidar de los coches aparcados en lugares públicos, propietarios de establecimientos comerciales, sobre todo bares y restaurantes. Las prácticas que alteran la visibilidad y la movilidad en esa zona.
Las numerosas funciones actuales en el Plano Piloto revelan la reunión y la confrontación de diferentes órdenes urbanos. Por lo tanto, muestran cómo la complejidad metropolitana actúa en el marco de ese espacio. El icono brasiliense se vuelve polisémico. El icono expresa y comunica algo más allá de la pretensión de homogeneidad de la nación republicana. 
Imágenes: Región Administrativa de Guará
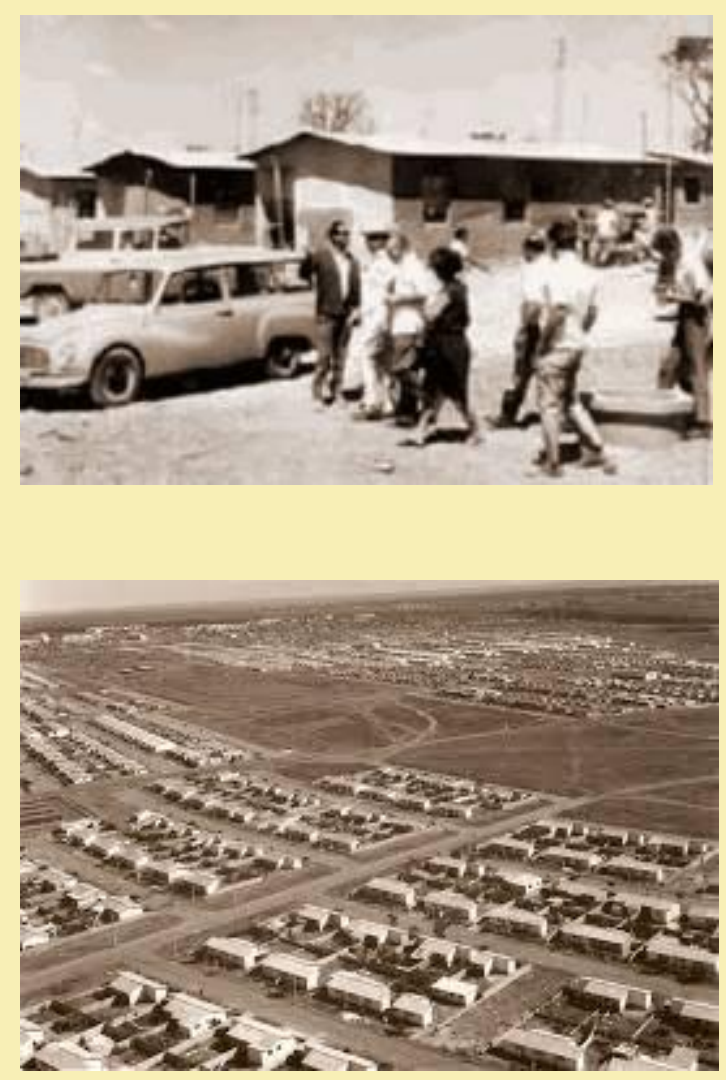
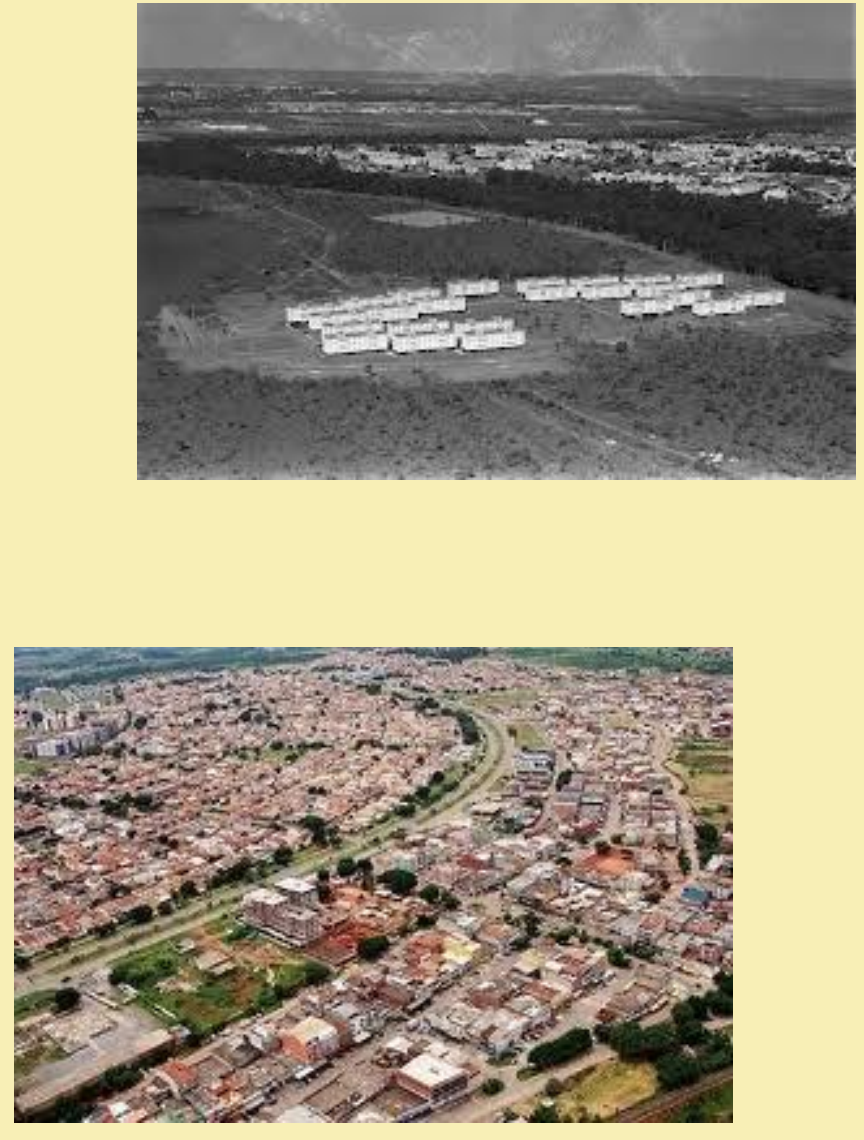

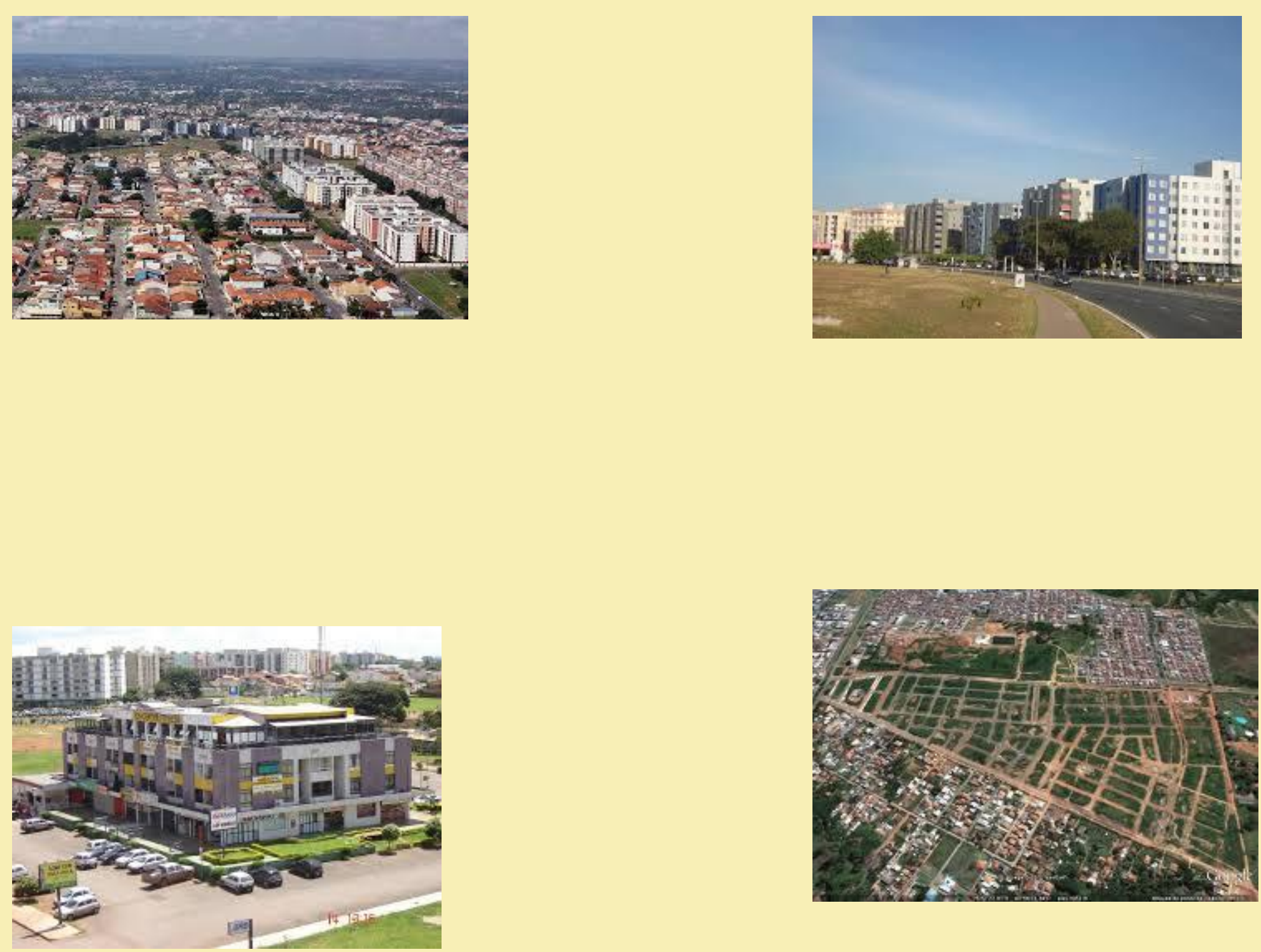

Dossiê Expressões Artísticas e Mulheres

Arquivos do CMD, Volume 2, N. 2. Jul/Dez 2014 


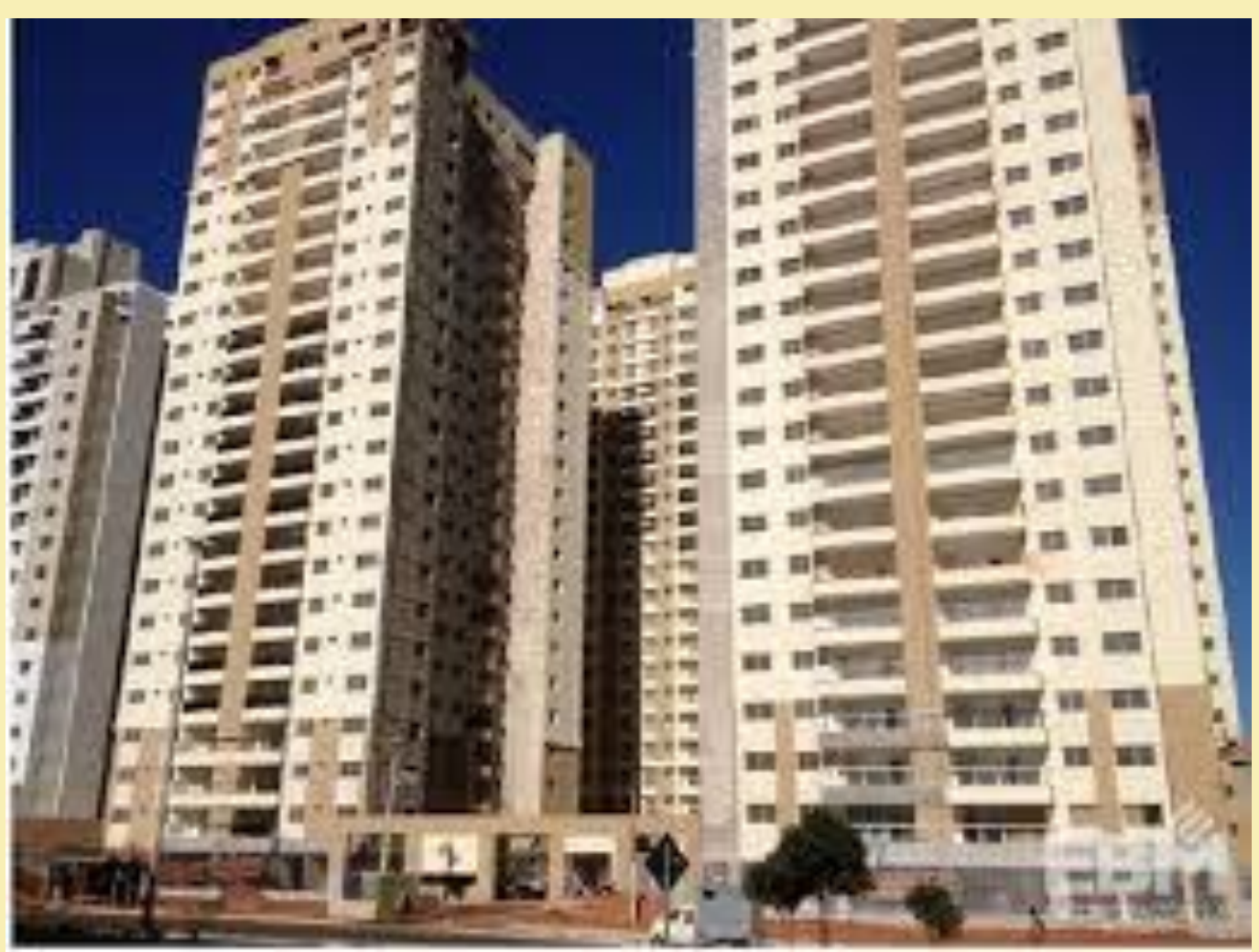


Imágenes: Ciudad de Luziânia (Estado de Goiás), parte de la RIDE

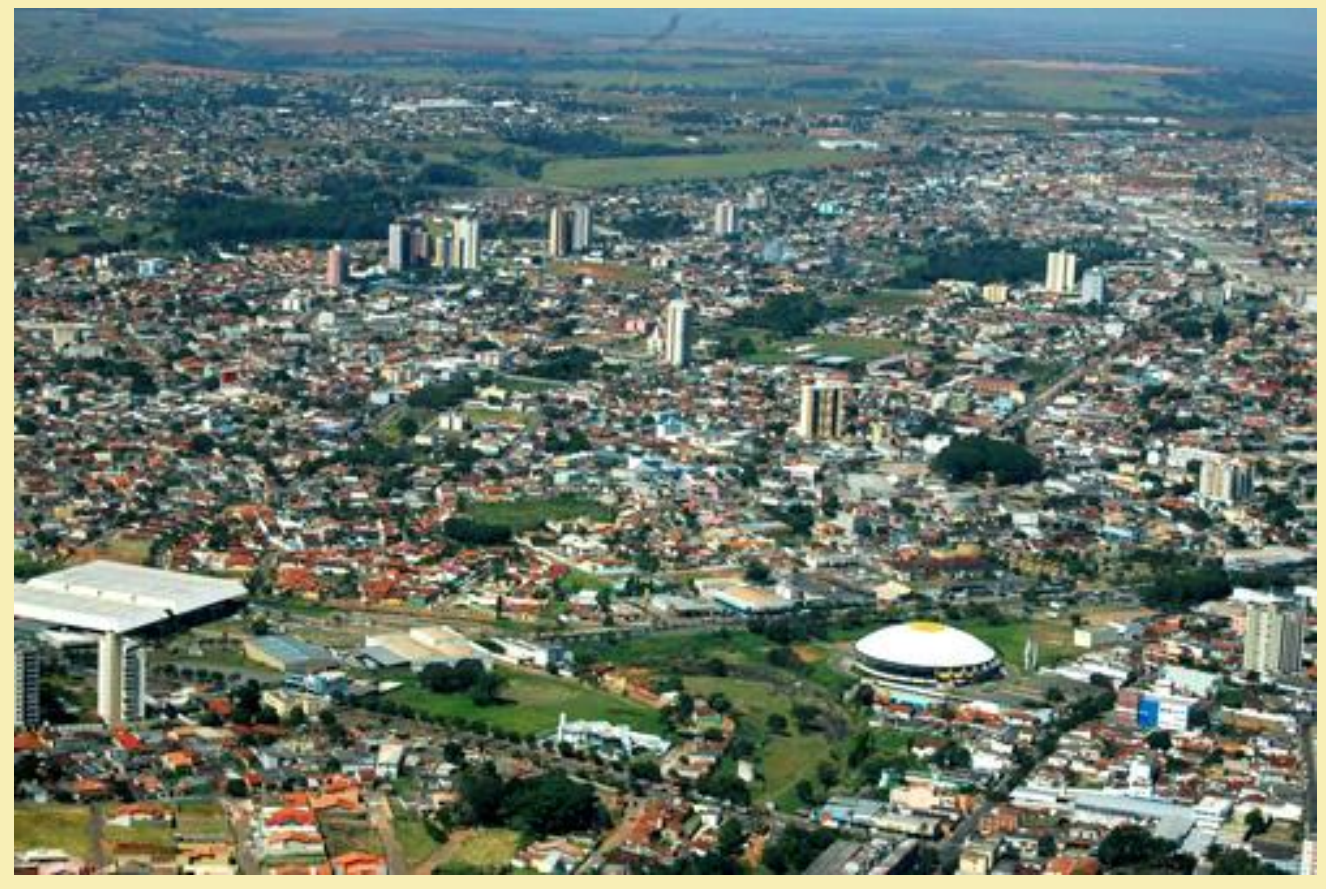




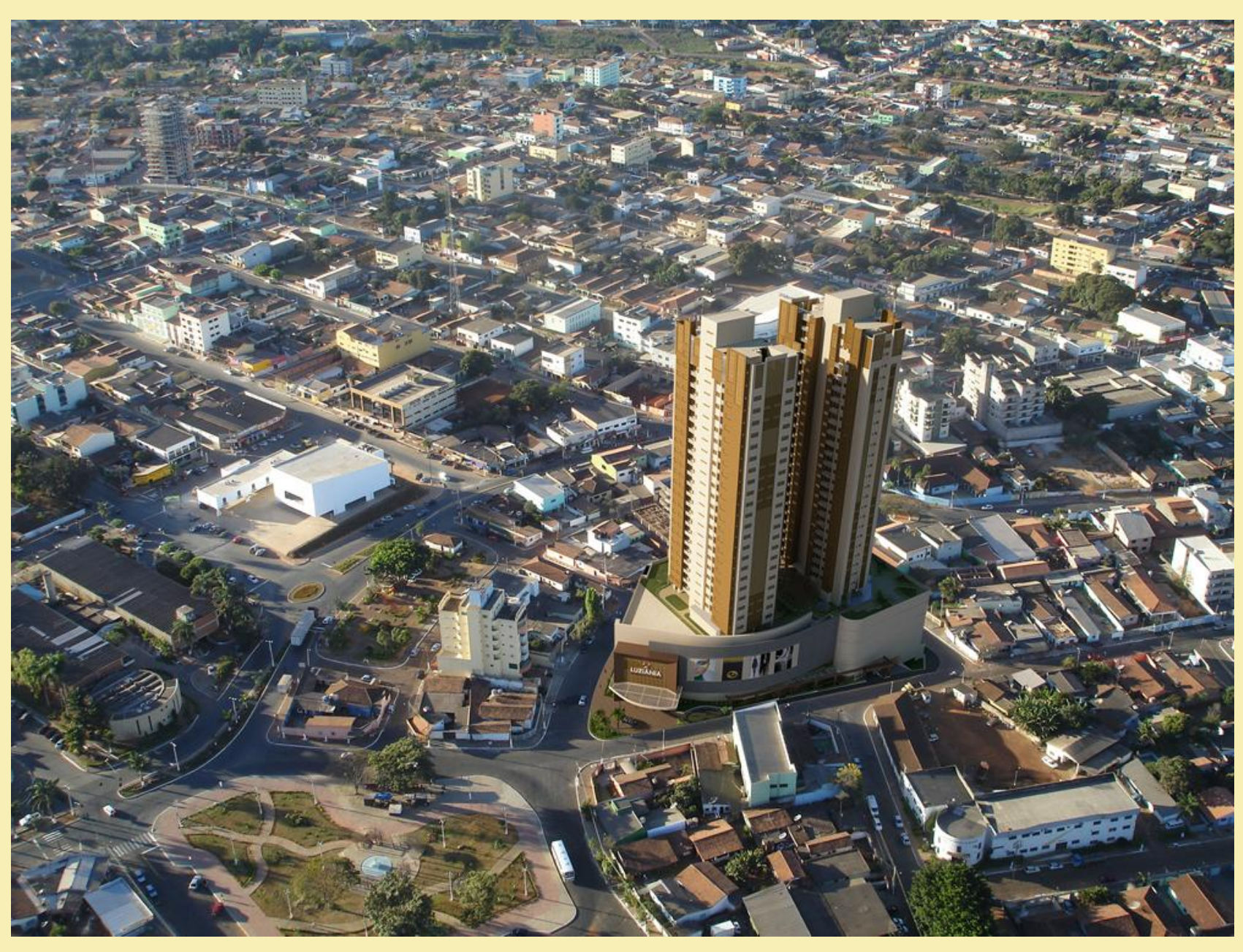


Imágenes: La Comunidad (Favela) de La Vila Estrutural

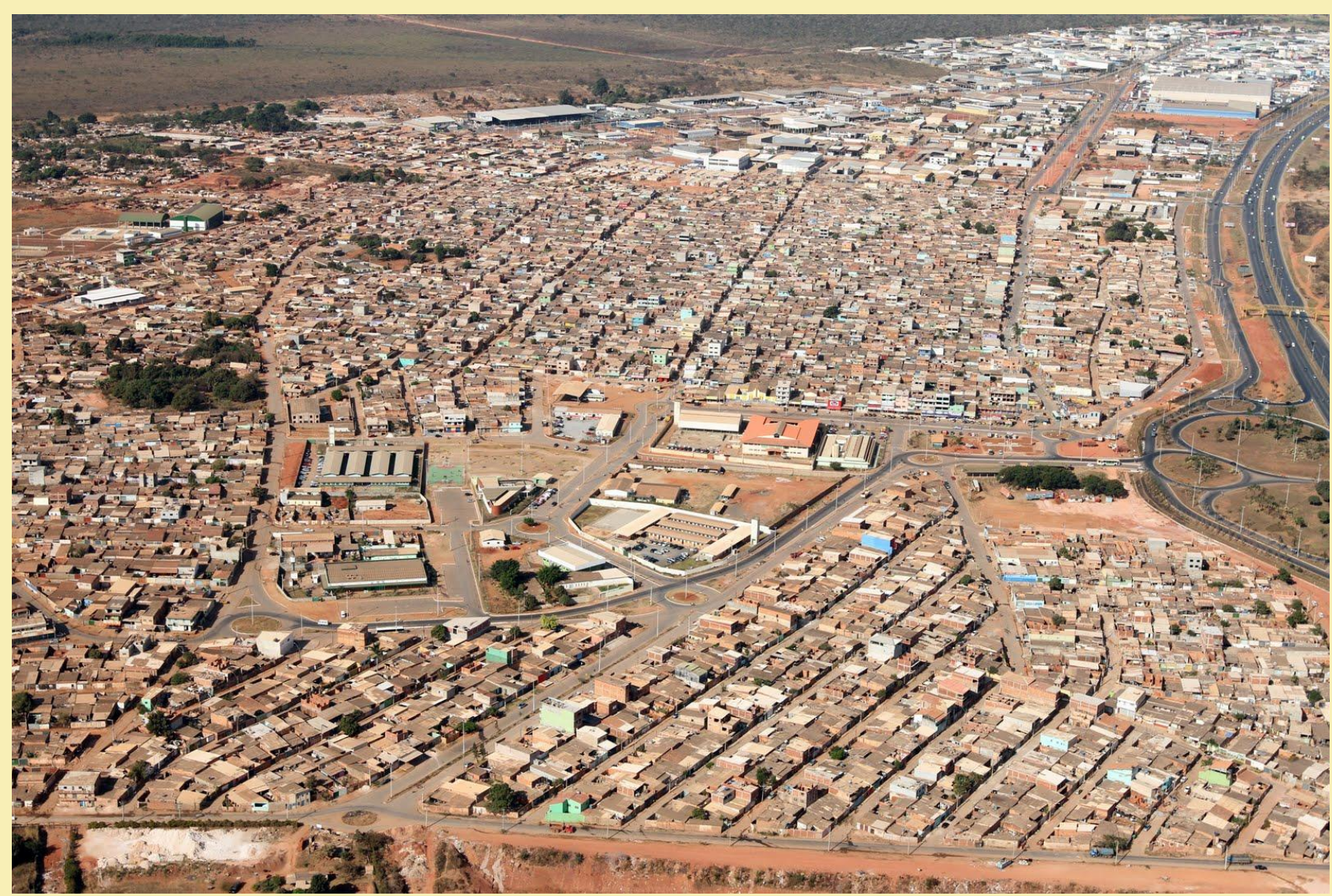




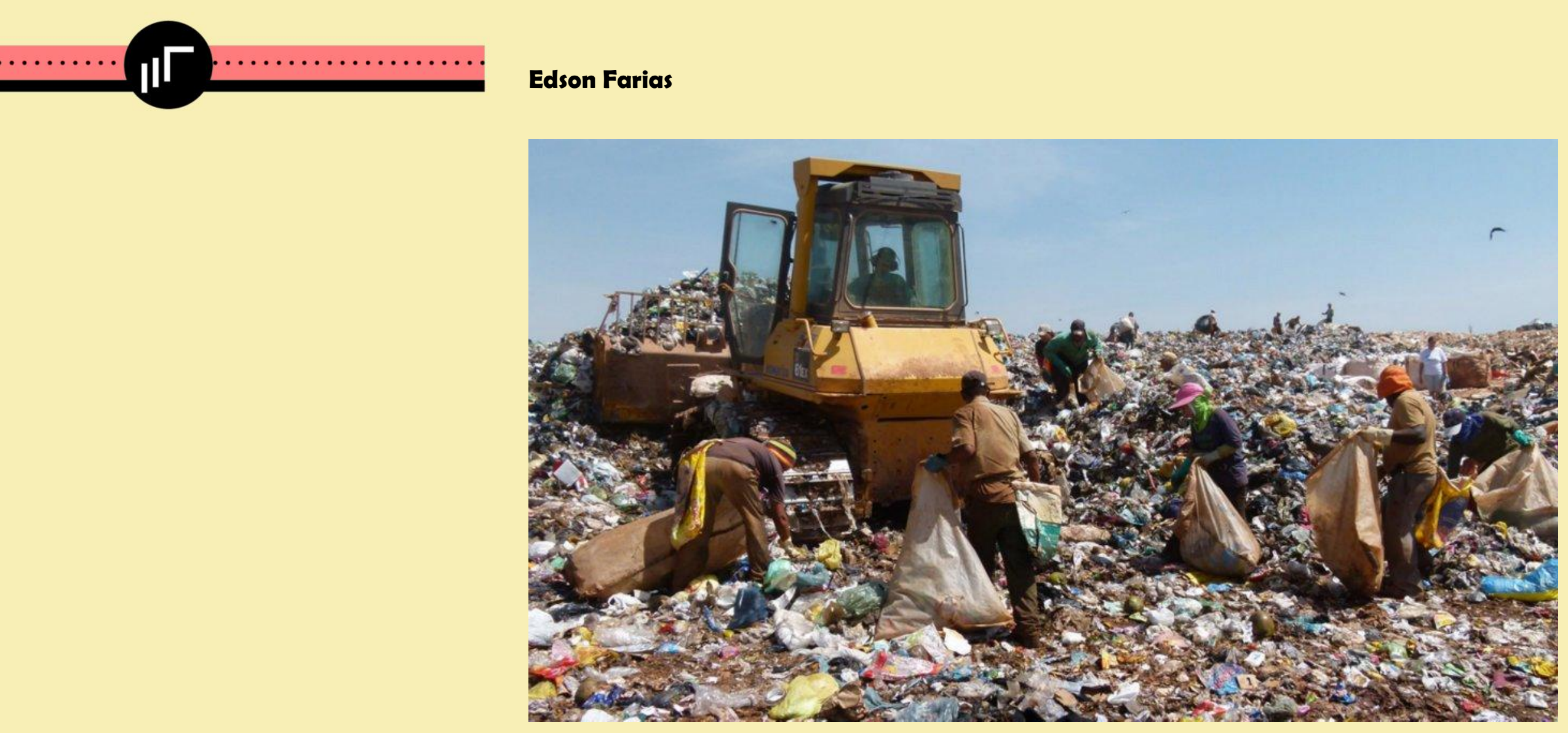




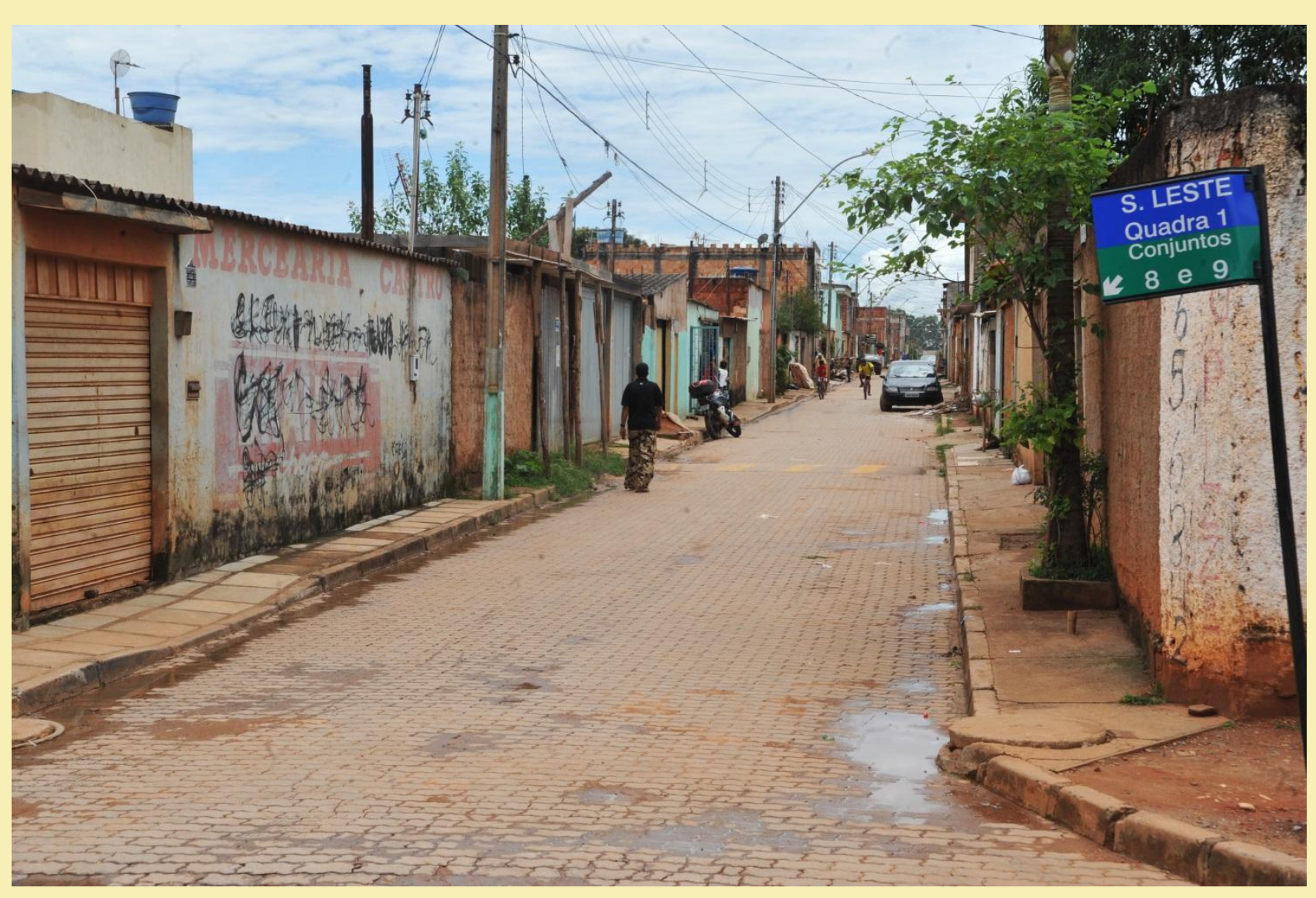




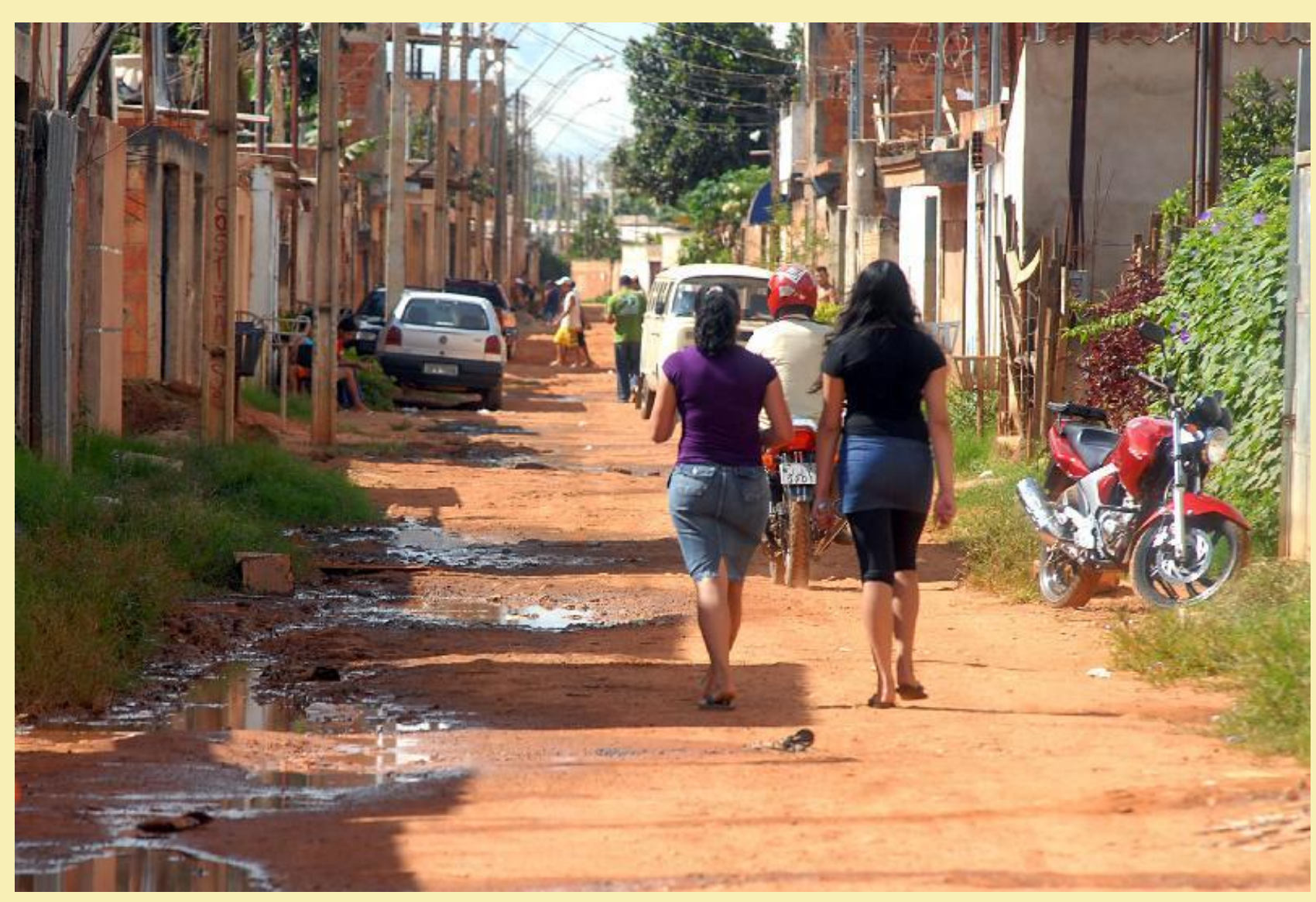

Imágenes: Condomínios cerrados 


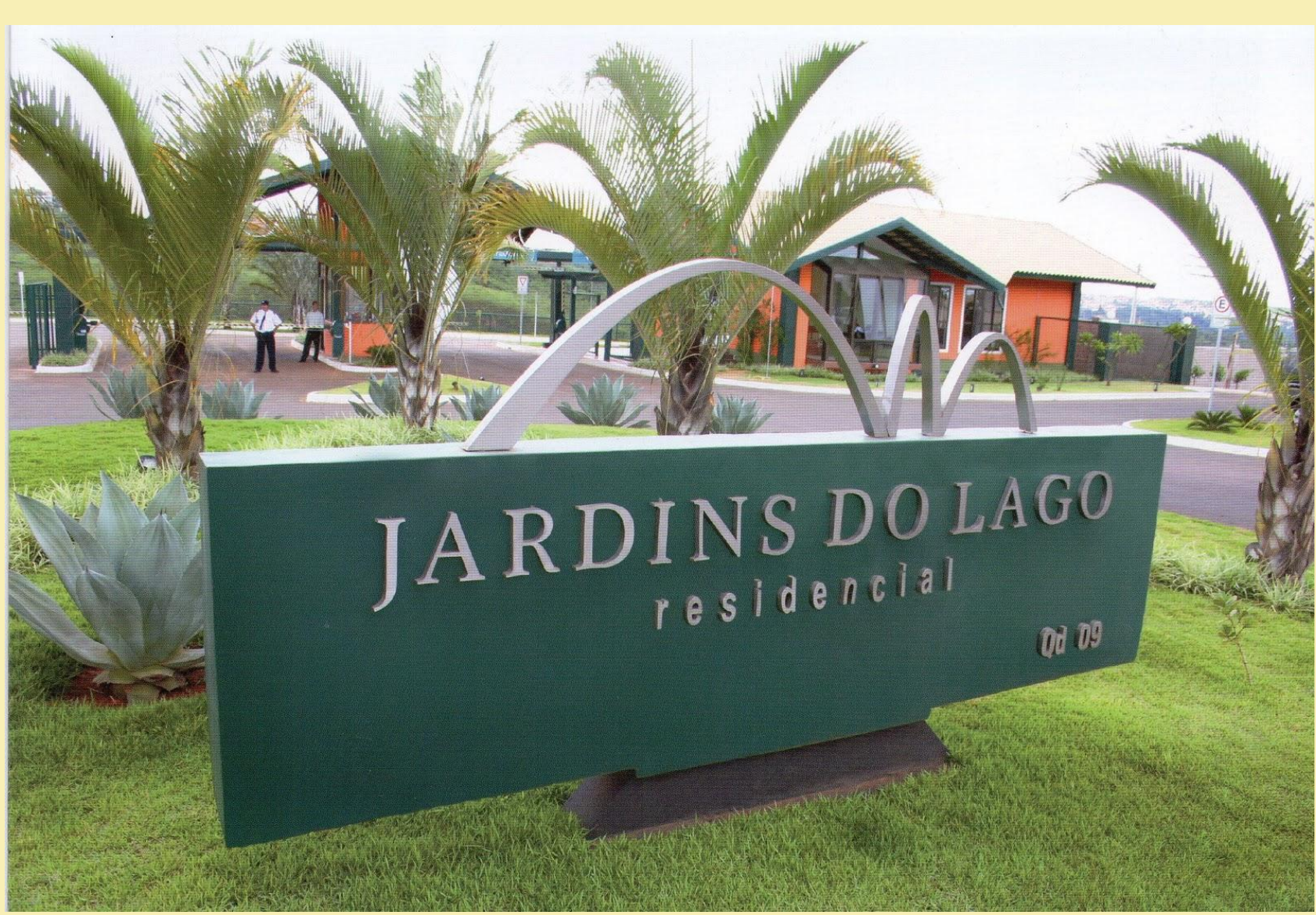




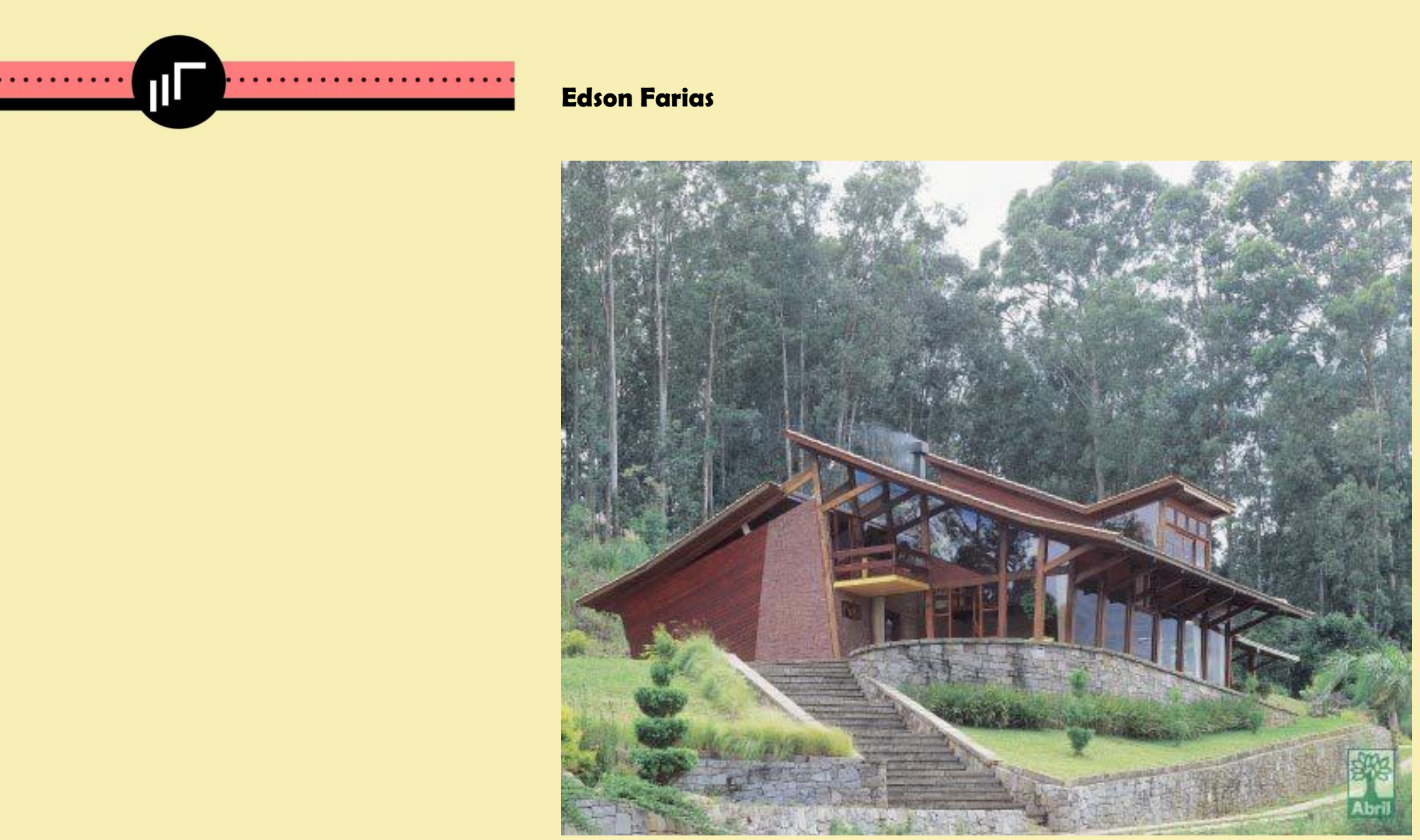

Imágenes: Sectores Bancário Comercial Norte e Sul 


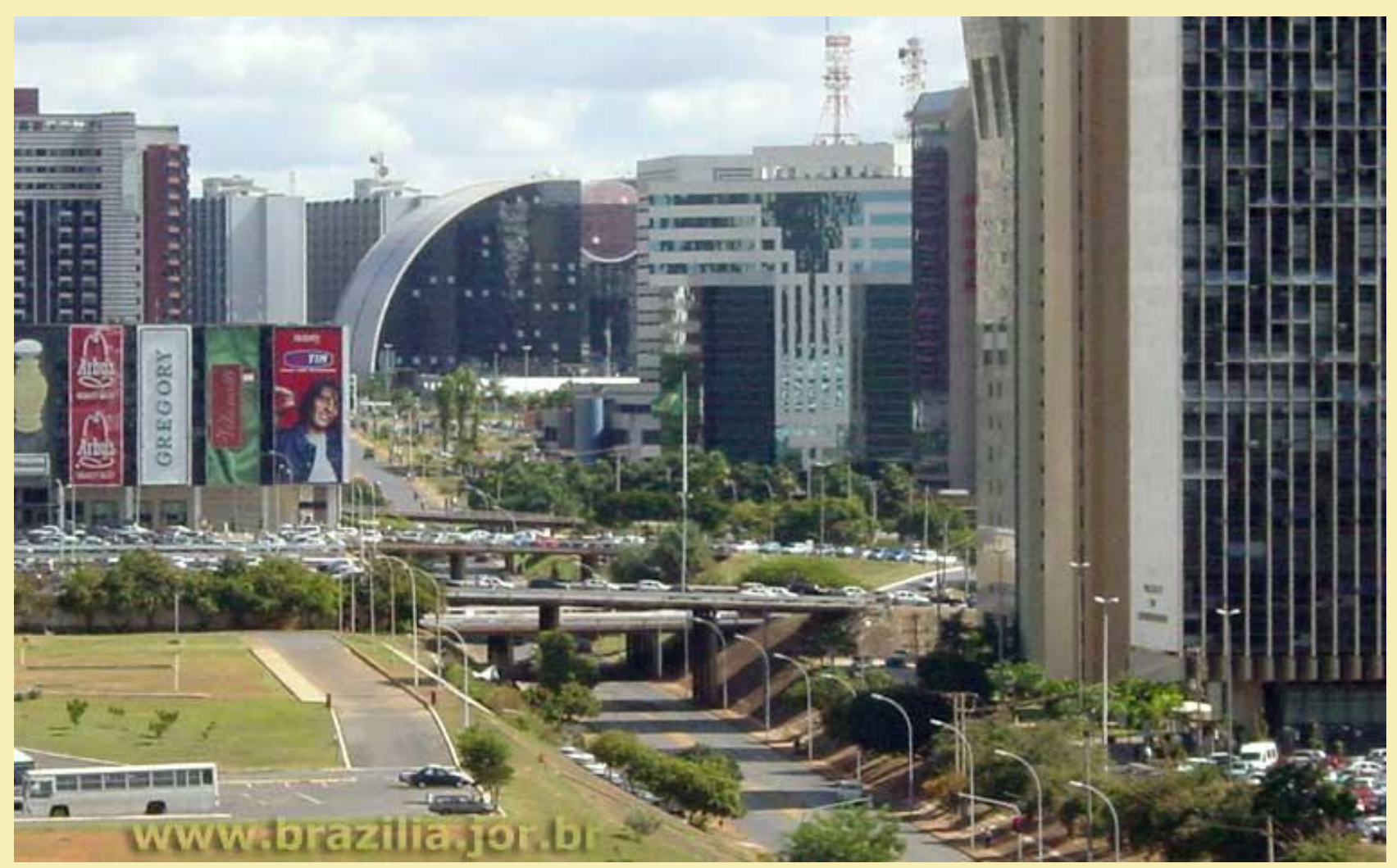




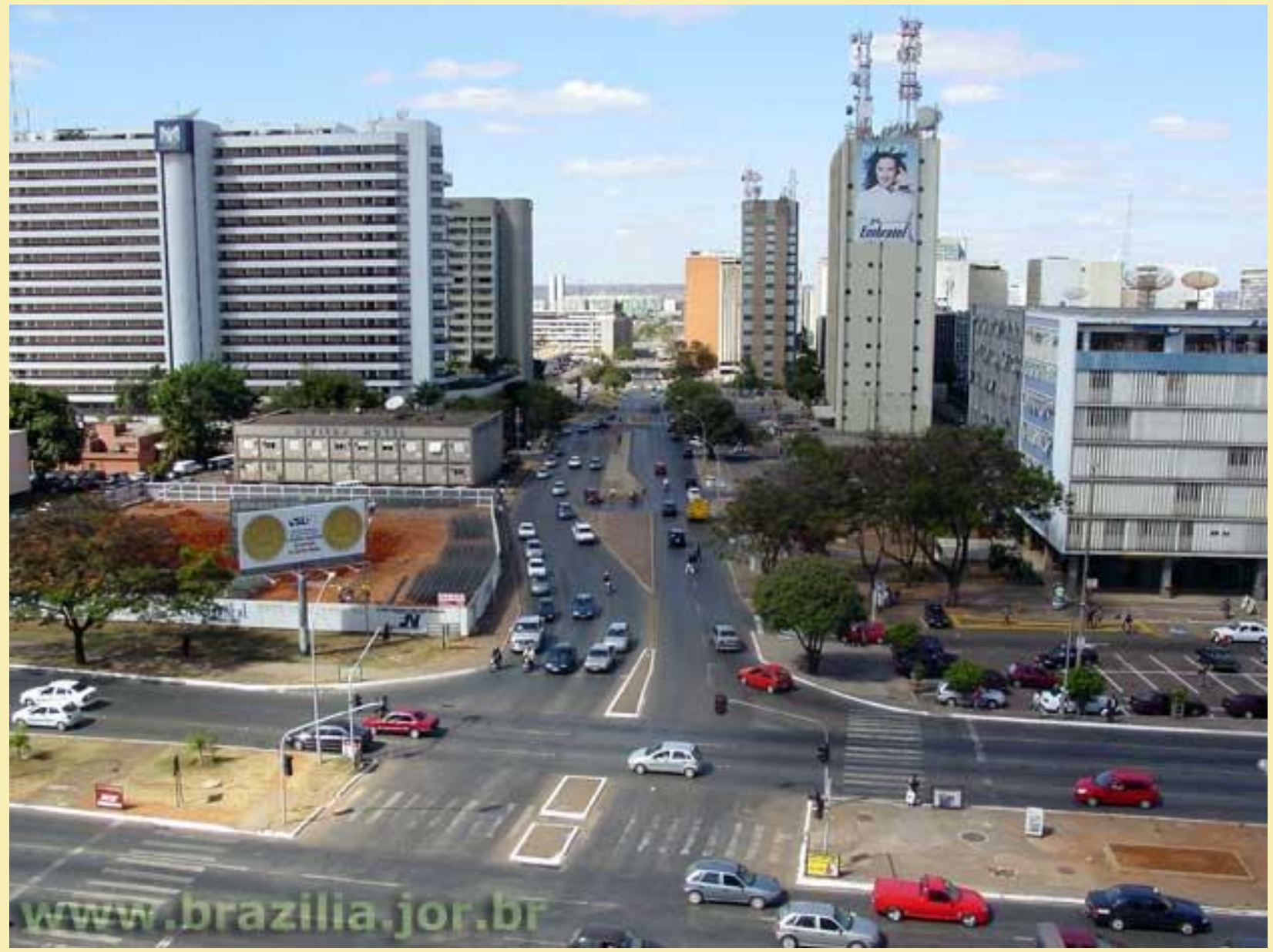




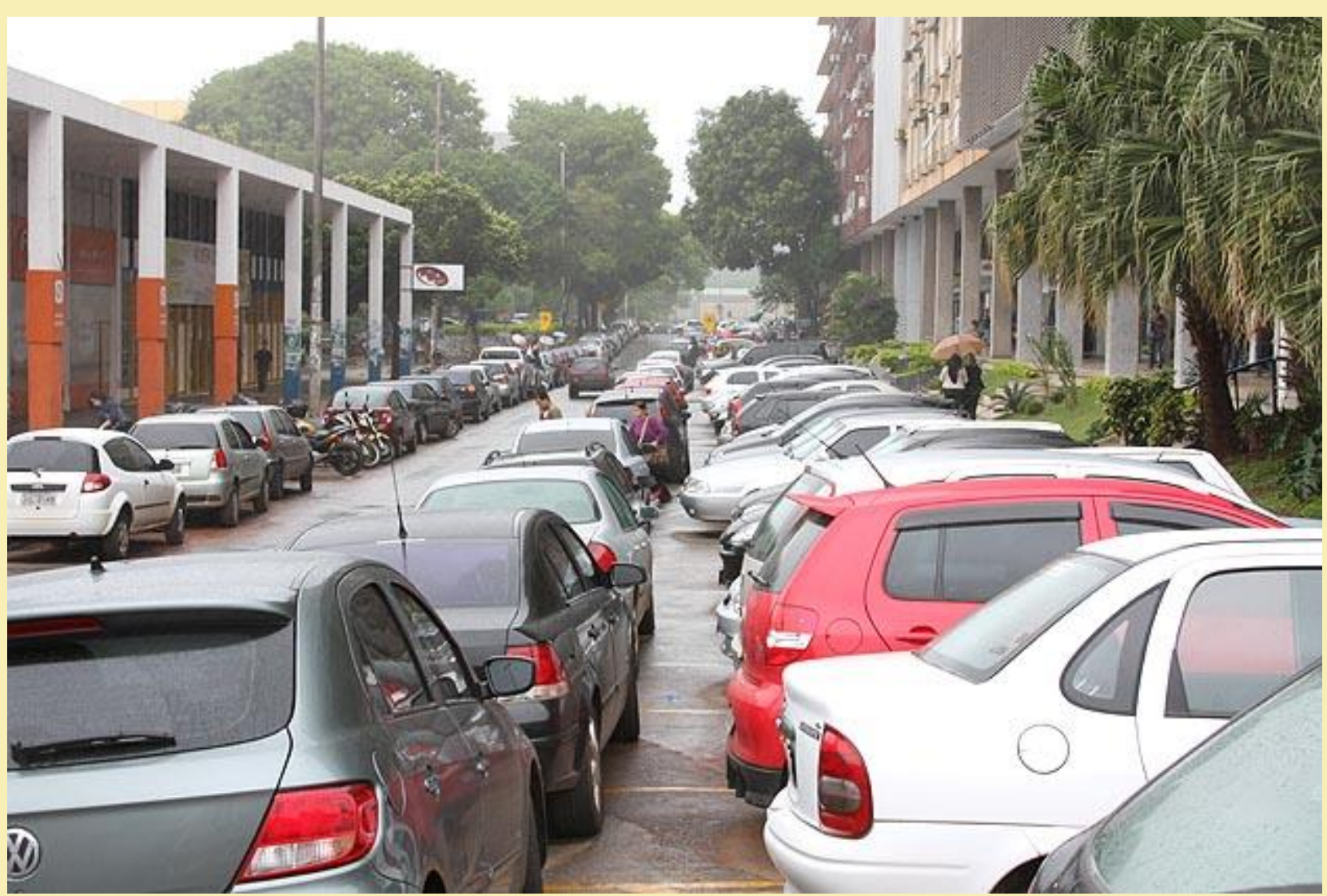




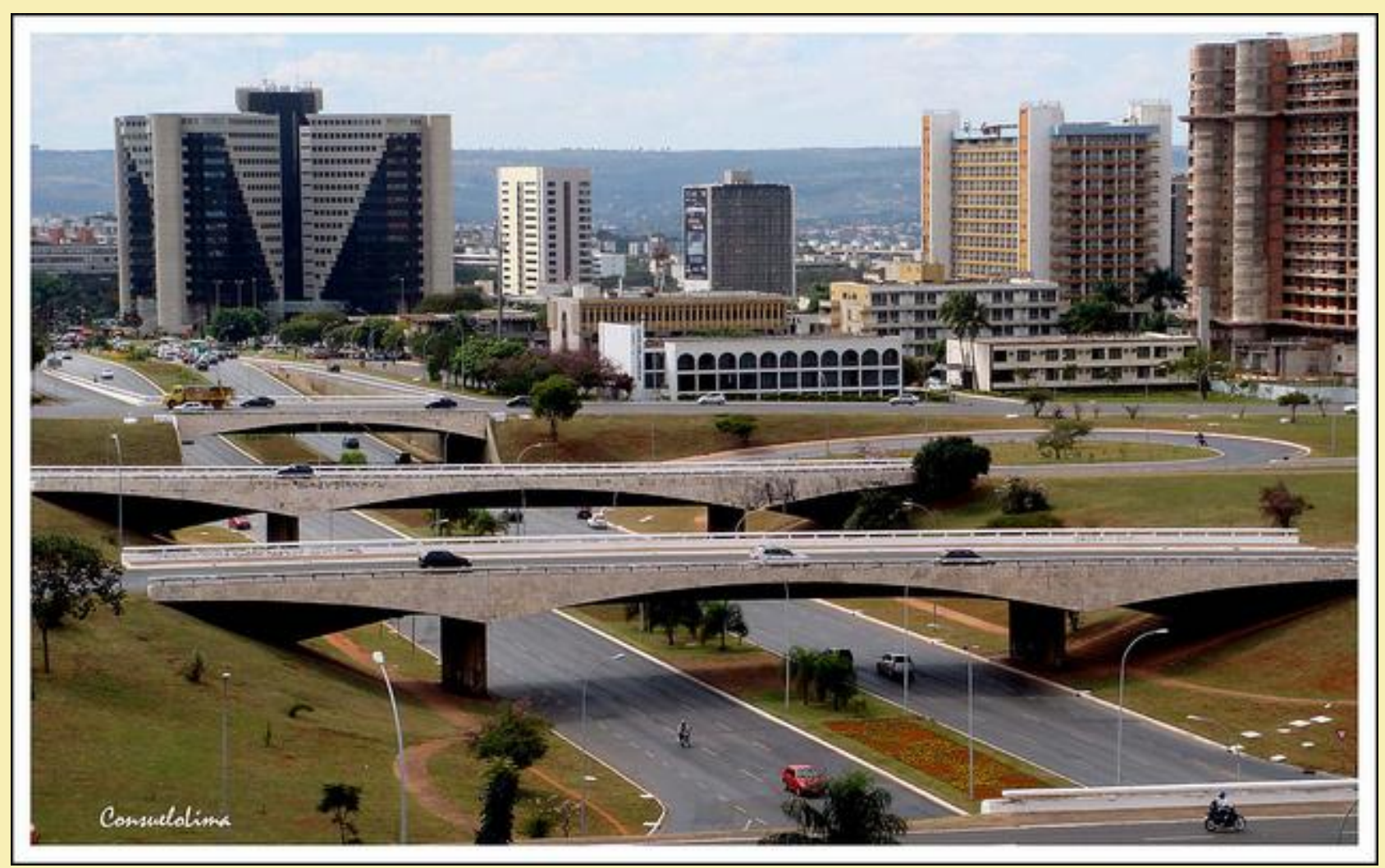




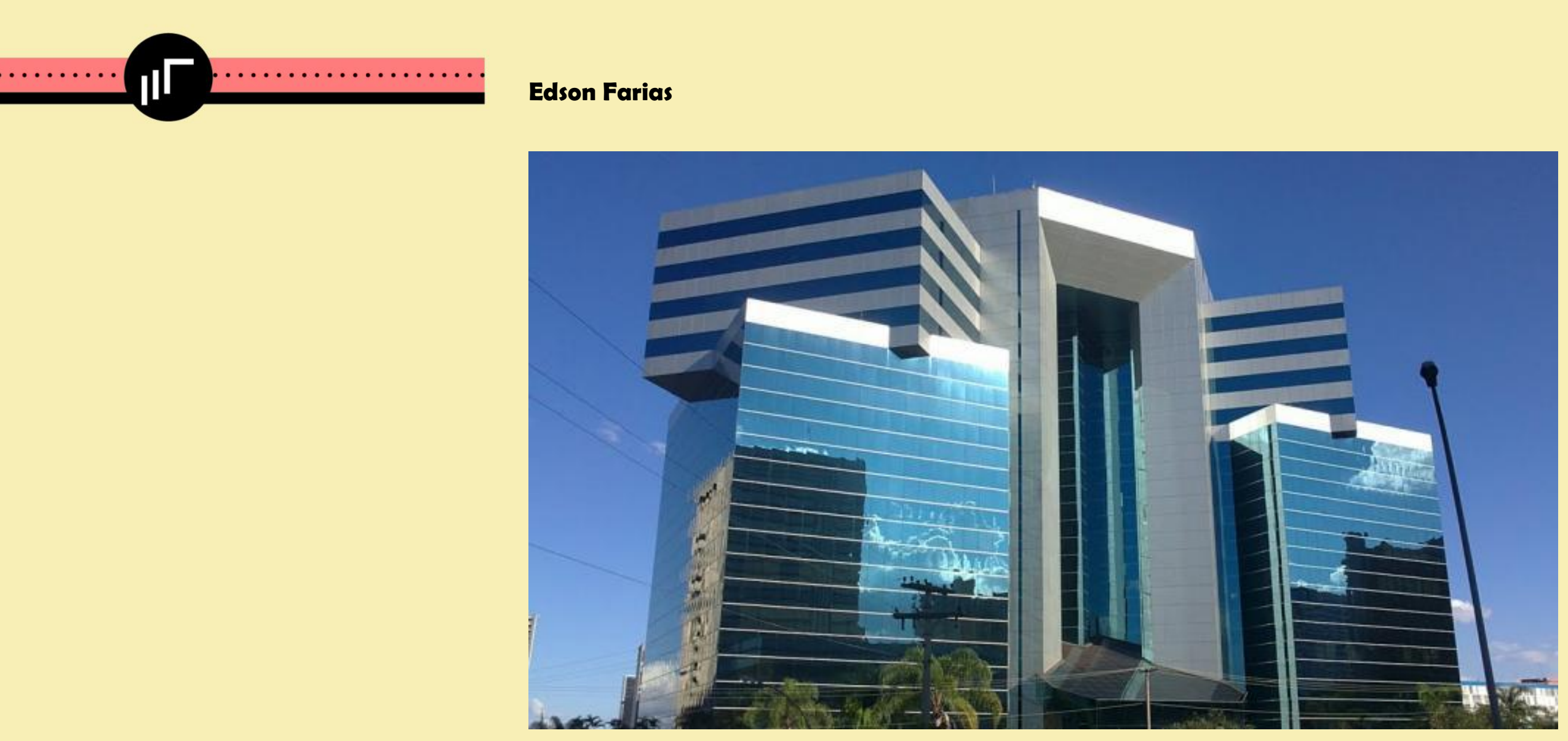




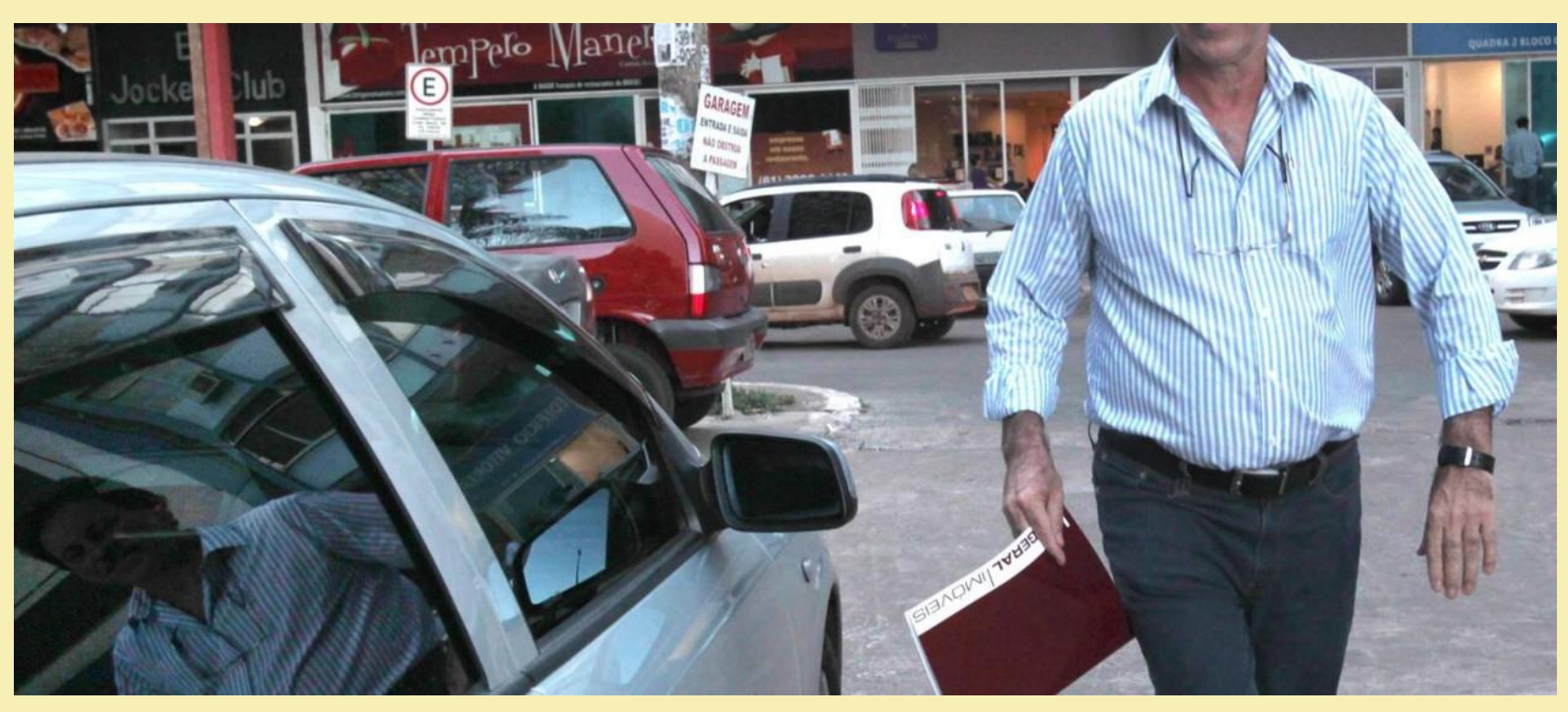




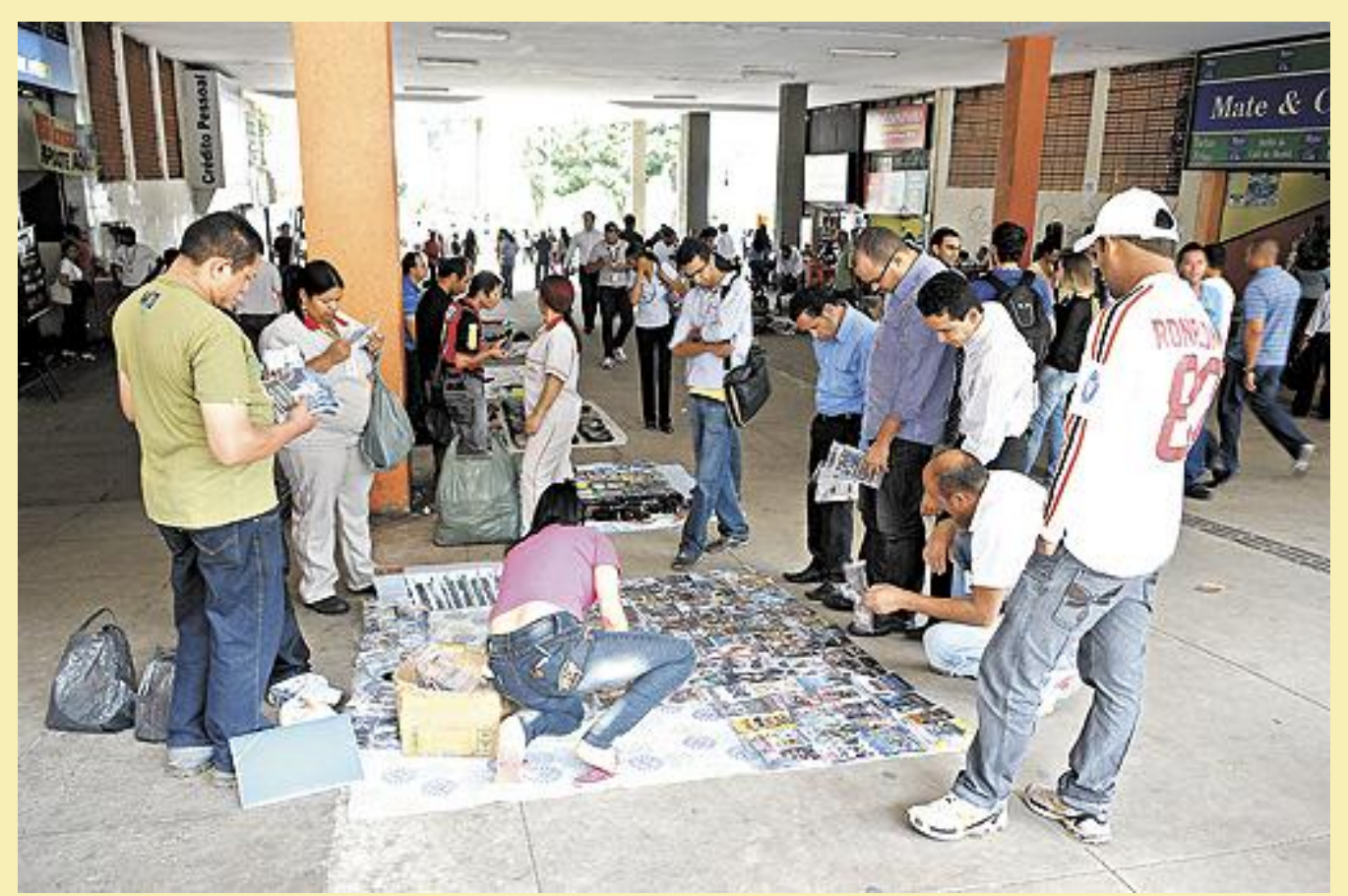

Imágenes: Super cuadras en Plano Piloto 


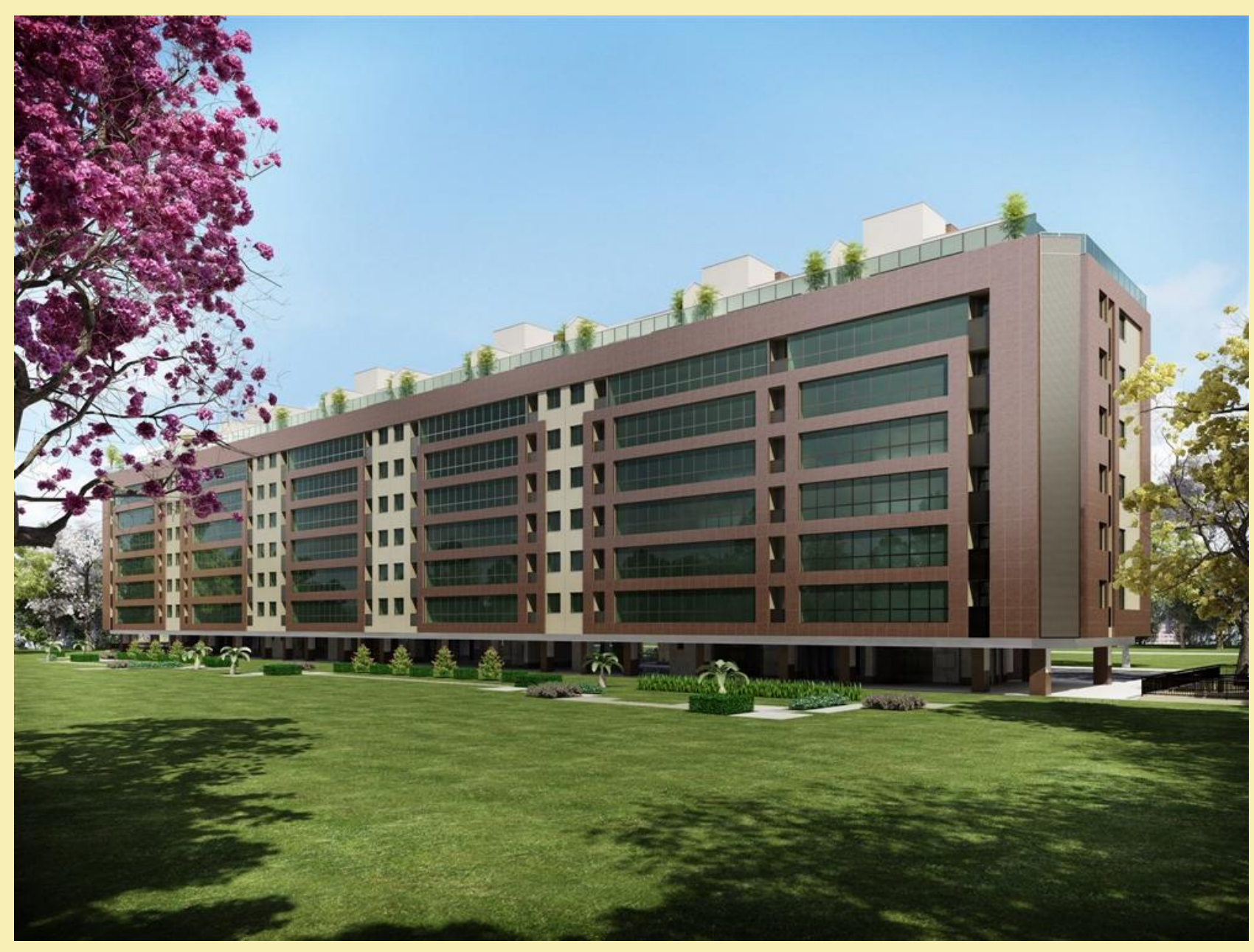




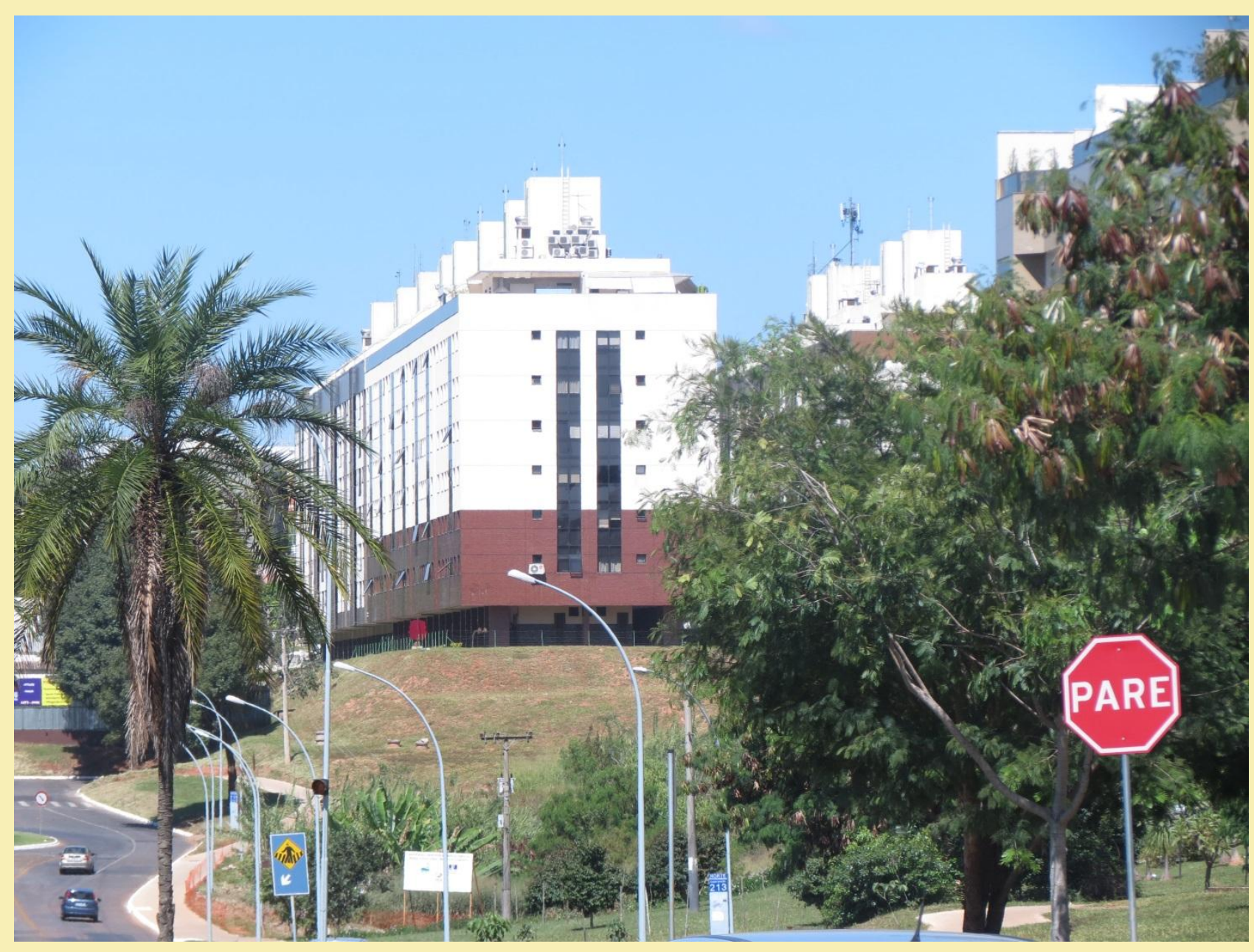


no podríamos terminar esta presentación sin hacer alusión a un episodio que se repitió a lo largo de las cinco sesiones en que hicimos grupos focales. Los episodios reclamaron nuestra atención a la manera como, en medio a las transformaciones urbanas reverberadas en la diversidad de usos socio-espaciales, el icono sigue siendo un factor de guía. Más aún. Algo para lo cual se canalizan los sentimientos.

En todas las sesiones, excepto los que viven en el Plan Piloto, los residentes de otras áreas administrativas y también ciudades que conforman el contexto metropolitano de Brasilia subrayaron los beneficios de estos lugares. La tendencia era establecer contrastes entre las formas de vida de sus regiones con lo que les parecía ser un comportamiento hostil de los residentes del Plano Piloto. Sin embargo, en general, en el momento en que proyectábamos imágenes del Plano, sus palabras se volvieron reverentes. Se destacaron las proporciones armoniosas de las formas. Se pusieron de relieve la belleza y la serenidad de las super cuadras. Señalaron la posibilidad de contacto directo con la naturaleza en un centro urbano. Y a menudo oímos repetir frases completas contenidas en el documento firmado por Lúcio Costa y Oscar Niemeyer. 